\title{
A Quarta Proposição de J. S. Mill na Teoria Austríaca dos Ciclos Econômicos
}

\author{
Ubiratan Jorge Iorio*
}

\begin{abstract}
Resumo: Na Quarta Proposição Fundamental de J. S. Mill, formulada em 1848, o autor sugere que a demanda de bens de consumo e a demanda de investimentos podem mover-se em sentidos opostos, em contraste com os modelos macroeconômicos modernos, nos quais os níveis de gastos de consumo e de investimento movem-se no mesmo sentido. Neste artigo, meu propósito é mostrar o papel que a Quarta Proposição Fundamental de J. S. Mill desempenha na Teoria Austríaca dos Ciclos Econômicos, de modo a comparar o posicionamento teórico austríaco com correntes macroeconômicas contemporâneas.

Palavras-chave: John Stuart Mill, Macroeconomia, Teoria Econômica, Teoria Austríaca dos Ciclos Econômicos.
\end{abstract}

\section{J. S. Mill's Fourth Proposition in the Austrian Theory of Economic Cycles}

\begin{abstract}
In the Fourth Proposition of J. S. Mill, formulated in 1848, the author suggests that the demand of consumer goods and the demand of investments can move in opposite directions, in contrast with modern macroeconomic models, in which the levels of consumption expenditures and of investment move in the same direction. In this article, my purpose is to show the role played by J. S. Mill's Fourth Proposition in the Austrian Theory of Economic Cycles, in order to compare the Austrian theoretic stance with contemporary macroeconomic streams.

Keywords: John Stuart Mill, Macroeconomics, Economic Theory, Austrian Theory of Economic Cycles.

Classificação JEL: A1, B53, E2
\end{abstract}

\footnotetext{
" Ubiratan Jorge Iorio é Professor Associado da Faculdade de Ciências Econômicas da Universidade do Estado do Rio de Janeiro (UERJ), visiting professor da Scuola di Liberalismo della Fondazione Vincenzo Scoppa na Itália, Presidente Executivo e CEO do Centro Interdisciplinar de Ética e Economia Personalista (CIEEP), Vice Presidente da instituição mantenedora e membro do Conselho Editorial de COMMUNIO: Revista Internacional de Teologia e Cultura, Diretor Acadêmico do Instituto Ludwig von Mises Brasil (IMB), e Editor Responsável de MISES: Revista Interdisciplinar de Filosofia, Direito e Economia. Cursou a graduação em Economia na Universidade Federal do Rio de Janeiro (UFRJ) e o doutorado em Economia na Escola de Pós-Graduação em Economia da Fundação Getulio Vargas do Rio de Janeiro (EPGE/FGV-RJ). Foi Economista do Banco Central, Diretor da Faculdade de Ciências Econômicas da UERJ e professor da FGV-RJ, da Pontifícia Universidade Católica do Rio de Janeiro (PUC-RJ) e do Instituto Brasileiro de Mercados e Capitais do Rio de Janeiro (IBMEC-RJ), além de ter atuado como colunista dos jornais Monitor Mercantil, O Dia, Jornal da Tarde e Jornal do Brasil. Em 2013 foi agraciado com o Premio Internazionale Liber@mente, conferido pela Scuola di Liberalismo della Fondazione Vincenzo Scoppa, em Catanzaro, Calábria, na Itália. É autor de inúmeros artigos publicados em jornais, revistas, sites na internet e periódicos acadêmicos, além de ter escrito seis livros, dentre os quais se destacam Economia e Liberdade: a Escola Austríaca e a Economia Brasileira (Forense Universitária, 1997), Ação, Tempo e Conhecimento: A Escola Austríaca de Economia (Instituto Ludwig von Mises Brasil, 2011), Dez Lições Fundamentais de Economia Austríaca (Instituto Ludwig von Mises Brasil, 2013) e Dos Pós-Escolásticos a Menger: Uma Breve História das Origens da Escola Austríaca de Economia (Instituto Ludwig von Mises Brasil, 2015).

E-mail: ubiratan@mises.org.br
} 


\section{I - INTRODUÇÃo}

A Quarta Proposição Fundamental de John Stuart Mill (1806-1876), formulada em 1848, no Livro I, capítulo V dos Principles $^{1}$, na forma de um aforismo ("demanda de mercadorias não é demanda de mão de obra") é um dos elementos decisivos para distinguir a "macroeconomia" dos austríacos - e particularmente a de F. A. Hayek (1899-1992) - da macroeconomia da economia mainstream. Em todos os modelos macroeconômicos modernos, de tintas keynesianas ou não, os níveis de gastos de consumo e de investimento movem-se no mesmo sentido. Nesta famosa proposição, contudo, Mill sugere que a demanda de bens de consumo e a demanda de investimentos podem mover-se em sentidos opostos. Tentaremos mostrar como John Maynard Keynes (1883-1946), noventa anos depois, demonstrou não ter compreendido sua essência, enveredando pelo caminho dos "agregados macroeconômicos", no que foi seguido pelos monetaristas. Tal postura influenciou praticamente toda a macroeconomia ensinada nas universidades, bem como as práticas dos governos de todo o mundo, desde os anos 30 do século XX.

A Teoria Austríaca dos Ciclos Econômicos [doravante TACE], plantada pelos protoaustríacos e pelo fundador da escola, Carl Menger (1840-1921), formulada por Ludwig von Mises (1881-1973) em seu tratado monetário de 1912, desenvolvida posteriormente por F. A. Hayek nos anos 30, explicada magistralmente por Murray Rothbard (1926-1995) e outros austríacos de renome e compatibilizada com a macroeconomia convencional de maneira bastante criativa por Roger Garrison, é formada por sete elementos, que podem ser assim isolados: $\left(1^{\circ}\right)$ o processo de mercado;

1 MILL, John Stuart. The Principles of Political Economy. New York: D. Appleton and Company, 1885.

${ }^{2}$ Para uma discussão mais aprofundada, ver o capítulo 7 de minha obra: IORIO, Ubiratan Jorge. Ação, Tempo e Conhecimento: A Escola Austríaca de Economia. São Paulo: Instituto Ludwig von Mises Brasil, 2011.
(2ㅇ) a doutrina da poupança forçada; ( $\left.3^{\circ}\right)$ a estrutura de capital da economia; $\left(4^{\circ}\right)$ o papel de coordenação intertemporal da taxa de juros; $\left.5^{\circ}\right)$ o efeito Ricardo, o efeito taxas de juros, o efeito preços relativos e o efeito concertina; $\left(6^{\circ}\right)$ a teoria hayekiana do conhecimento e $\left(7^{\circ}\right)$ a Quarta Proposição fundamental de John Stuart Mill.

Neste artigo, desejo mostrar o papel que o último desses elementos desempenha na TACE. Antes, parece conveniente ressaltar que embora a Escola Austríaca não contenha algo que se possa chamar de "macroeconomia", não existe nada de errado em utilizar este termo para que possamos compará-la com as teorias alternativas, das quais as principais são a teoria keynesiana e o monetarismo. De resto, os assuntos tratados pela macroeconomia e pela TACE são rigorosamente os mesmos, variando apenas a metodologia.

É oportuno fazer um pequeno resumo das seis primeiras proposições, tal como fizemos no livro mencionado ${ }^{3}$ e em diversos artigos ${ }^{4}$.

\section{I.1 - O Processo de Mercado}

Embora, para efeitos de exposição, Hayek tenha partido de uma situação que se abstrai da existência de recursos ociosos, sua teoria dos ciclos é essencialmente "austríaca" na medida em que trata os mercados como processos dinâmicos de descoberta e de coordenação. Como observou Fritz Machlup (1902-1983), a tese fundamental da teoria é que os ciclos são causados por fatores monetários, mas são constituídos por fatores reais. Esses últimos nada mais são do que o desenrolar do próprio processo de mercado em resposta a um choque que elimine a coordenação no mercado. Neste processo, os sinais emitidos pelos preços funcionam como elementos

\footnotetext{
${ }^{3}$ Idem. Ibidem.

4 Que podem ser encontrados em <http://www. ubirataniorio.org>.
} 
coordenadores: quando a manipulação monetária cria uma sinalização falsificada de preços, está plantada a semente da ausência de coordenação econômica.

\section{I.2 - A doutrina da poupança forçada}

Quando ocorre uma expansão na oferta de moeda, verifica-se uma inchação na oferta de fundos para empréstimos, o que introduz uma cunha entre poupança e investimento. A concepção de poupança forçada (que não deve ser interpretada como compulsória, mas como falsa, forçada, ilusória) de Hayek refere-se a uma situação ex-post: os consumidores descobrem que devem consumir menos do que haviam planejado para cada nível de renda e a poupança forçada é igual à diferença entre a poupança observada e a poupança planejada. Em outras palavras, a moeda nova fantasia-se de poupança, ao reduzir artificialmente a taxa de juros abaixo de seu nível natural (aqui, Hayek adotou a nomenclatura de Knut Wicksell (1851-1926)), fazendo com que a trajetória de investimentos se torne inconsistente com o montante de poupança real e com as preferências intertemporais de consumo, dando início a um processo de ausência de coordenação intertemporal.

\section{I.3 - A estrutura de capital}

Os bens de capital são heterogêneos e relacionam-se uns com os outros mediante diversos graus de complementariedade e substituibilidade, ao longo dos diversos estágios que caracterizam a estrutura de produção, que vão desde os bens de primeira ordem (de consumo final) até os bens de ordens mais elevadas (de investimento). Tanto estes como os primeiros são intertemporalmente complementares: taxas de juros artificialmente baixas eliminam a coordenação intertemporal, que se manifesta inicialmente na forma de sobreinvestimentos em bens de capital (isto é, em bens de ordens mais elevadas). Na linguagem dos economistas austríacos, a estrutura de produção torna-se mais indireta (roundabout), isto é, aumenta o número de estágios que a compõem. Mas, com o decorrer do tempo e a consequente escassez dos bens de capital (complementares) de ordens inferiores, a ausência de coordenação intertemporal acabará sendo revelada, o que levará a uma tentativa da economia (isto é, das ações humanas individuais) de retornar à estrutura de produção inicial (menos roundabout, ou seja, mais direta).

A estrutura de produção pode ser representada por uma série de retângulos em que, da direita para a esquerda, caminhamos dos bens de ordens menos elevadas (de consumo) para os de ordens mais elevadas (de capital). $\mathrm{O}$ eixo horizontal mede o tempo envolvido na estrutura de produção e a altura de cada retângulo reflete o valor de produção (preço vezes quantidade) em cada diferente estágio de produção. $\mathrm{O}$ último estágio à direita da estrutura de produção mede, obviamente, o valor do bem de consumo final.

\section{I.4 - O papel de coordenação intertemporal da taxa de juros}

A função principal da taxa de juros na concepção austríaca (especialmente em Eugen von Böhm-Bawerk (1851-1914)) é a de servir como elemento de coordenação entre as trajetórias de consumo e investimento (e, obviamente, de poupança). O tempo de produção (ou período de produção, na linguagem de Böhm-Bawerk), é uma variável endógena, na medida em que determinará a existência ou não de coordenação entre as decisões de produção e de consumo. E a taxa de juros é justamente a variável que, incorporando o tempo, afeta ambas as decisões.

Assim, quando a taxa de juros estiver em seu nível natural, isto é, quando for determinada exclusivamente pelas preferências intertemporais e pela demanda de investimentos, haverá coordenação entre as trajetórias 
de consumo e de investimento; quando não estiver, não existirá essa coordenação, o que significa que haverá desequilíbrios fatais entre a demanda e a oferta ao longo da estrutura de produção.

\section{I.5 - O efeito Ricardo, o efeito taxas de juros, o efeito preços relativos e o efeito concertina}

\section{I.5.a - Efeito Ricardo}

Em sua formulação original, o efeito Ricardo dizia respeito à substituição de mão de obra (fator de produção de curto prazo) por capital (fator de produção de longo prazo), como decorrência de uma redução na taxa de juros. No contexto da teoria hayekiana dos ciclos, entretanto, a substituição não se dá entre "homem" e "máquina", mas sim entre bens de capital de ordens menos elevadas e de ordens mais elevadas: na fase inicial do ciclo, a taxa de juros artificialmente baixa estimula os investimentos em bens de capital de ordens mais elevadas; com a consequente disputa por bens de capital de ordens mais baixas (complementares) os preços destes últimos aumentam, o que provoca um aumento na demanda por crédito (desperation borrowing) e o subsequente aumento da taxa de juros, o que, por sua vez, encoraja a liquidação dos projetos de produção iniciados na primeira fase, mas ainda não terminados. Em resumo, o efeito Ricardo original refere-se à substituição de homens por máquinas, quando os salários nominais aumentam e/ou os preços dos bens caem, enquanto o efeito Ricardo hayekiano diz respeito à substituição de métodos mais indiretos por métodos menos indiretos, em decorrência de aumentos salariais e/ou quedas nos preços.

\section{I.5.b - Efeito taxas de juros}

À medida que a taxa de juros cai, os retornos aumentam em geral, mas os proces- sos mais indiretos ficam relativamente mais lucrativos. A isto os austríacos denominam capital deepening, ou aprofundamento do capital, para indicar que a base do triângulo de Hayek se alarga, com a criação de novos estágios de produção à esquerda, mais afastados, portanto, do estágio do bem de consumo final ou bem de primeira ordem.

E, conforme a taxa de juros aumenta, os retornos caem em geral, mas com um viés em favor dos processos de produção mais diretos. Nesse caso, tende a acontecer um estreitamento da base do triângulo de Hayek, ou capital shallowing.

Existe, portanto, uma assimetria nos switches de curto para longo prazo e de longo para curto prazo, ou seja, variações na taxa de juros não afetam de maneira proporcional todos os setores da estrutura de produção. As variações na taxa de juros afetam a economia de uma forma desigual ao longo da estrutura de produção. Essa constatação não é considerada pelos modelos macroeconômicos, em que mudanças na taxa de juros afetam toda a economia por igual, de modo uniforme.

\section{I.5.c - Efeito preços relativos}

O aprofundamento dos processos de produção (capital deepening) permite obter quantidades de produto maiores a partir de um dado volume de fatores de produção; mas estes bens só estarão disponíveis posteriormente, e tanto mais posteriormente quanto mais indireto for o processo de produção. Eis a decisão econômica: é mais lucrativo manter ou alterar a estrutura de produção? A resposta vai depender da comparação entre o preço recebido pelo bem final e os preços que devem ser pagos pelos bens intermediários.

Tomemos o caso de uma expansão na oferta de moeda. Ela reduz a taxa de juros, o que aumenta o grau de roundaboutness, isto é, acontece um alargamento da estrutura de produção. Com isso, os preços dos bens finais subirão comparativamente aos preços dos bens mais distantes do consumo final, o que elevará os rendimentos nos setores produtores dos 
primeiros e provocará, assim, uma redução no grau de roundaboutness. Hayek denominou isto, como vimos, de efeito Ricardo que, em sua formulação original, referia-se à substituição de mão-de-obra (fator de produção de curto prazo) por capital (fator de produção de longo prazo), em decorrência de uma redução na taxa de juros. Mas, para Hayek e os austríacos, a substituição relevante não é entre "homem" e "máquina", mas entre bens de capital de ordens menos elevadas e de ordens mais elevadas ao longo da estrutura de capital. Na fase inicial do ciclo, a taxa de juros artificialmente baixa estimula os investimentos em bens de capital em estágios mais afastados do consumo final. Isto provocará uma disputa por bens de capital de ordens mais baixas complementares aos de ordens mais elevadas - fazendo subir os seus preços, o que provoca um aumento na demanda por crédito (desperation borrowing) e o subsequente aumento da taxa de juros, o que, por sua vez, encoraja a liquidação dos projetos de produção iniciados na primeira fase, mas ainda não terminados.

\section{I.5.d - Efeito concertina}

O efeito Ricardo produz o impacto inicial de aumentar o produto (embora o nível de investimento não mude), mas produz o fenômeno do capital shallowing ou efeito concertina - em português, algo como efeito sanfona, já que a concertina é um instrumento musical com fole, semelhante a um acordeão, em que, ao abrir-se o fole pressionando um botão, obtém-se uma nota musical e, ao fechar o fole, tem-se outra nota.

$\mathrm{O}$ efeito concertina refere-se, portanto, ao fato de que a poupança forçada incentiva inicialmente métodos de produção mais indiretos, mas, após algum tempo, os investimentos acabam sendo realocados para os métodos menos indiretos, fazendo com que a estrutura de capital "estique" e "encolha", tal como uma sanfona. No final das contas, o estoque de capital "agregado" ou capital fixo diminui. Esta proposição é que os economistas keynesianos, entre eles Nicholas Kaldor
(1908-1986), que criticou a teoria hayekiana, não foram capazes de entender.

A conclusão é que a expansão monetária e a queda da taxa de juros encorajam investimentos em capital em geral, especialmente os mais indiretos, mas o efeito subsequente de elevação dos preços dos bens finais tende a anular este viés, antes mesmo que a taxa de juros aumente. No fim, vem a recessão, mas a facilidade de recursos e a queda dos rendimentos nos estágios de bens finais deflagram o efeito Ricardo reverso. Assim, começam novamente a tornar-se atrativos os investimentos em métodos de produção mais indiretos.

O boom artificial induzido pela expansão monetária provoca, após algum tempo, distorções consideráveis na estrutura de produção. Mesmo antes do aumento na taxa de juros, as subidas nas taxas de retorno fazem com que projetos investimentos de investimentos que pareciam lucrativos tornarem-se não lucrativos e serem abandonados. Quando a taxa de juros subir - o que acontecerá em decorrência da disputa pelo crédito entre os setores mais próximos e os mais afastados dos bens de consumo final - ocorrerá uma aceleração nesse processo. Adicionalmente, os efeitos da queda na renda nesses setores agora não mais lucrativos causarão queda na demanda de bens de consumo final e mais desemprego. A queda na demanda de bens intermediários da estrutura de produção, gerada pela menor demanda de bens finais, será mais um agravante.

\section{I.6 - A teoria hayekiana do conhecimento}

A manipulação monetária ilude os participantes dos mercados, fazendo com que eles se comportem de modo diferente do que imaginavam; isto é possível porque o conhecimento sempre é insuficiente. Para Hayek, há dois tipos de conhecimento: o científico e o dos participantes dos mercados. Pode-se esperar que os participantes dos mercados - 
dado o seu conhecimento das circunstâncias particulares de tempo e lugar - sejam induzidos pelos preços de mercado a comportar-se "como se" possuíssem o conhecimento científico, isto é, como se compreendessem a estrutura do sistema econômico; mas não se pode esperar que possam interpretar instantaneamente como tais as distorções de preços provocadas pela manipulação monetária, com base em um conhecimento científico da estrutura da economia.

\section{II - As Quatro Proposições Fundamentais de John Stuart Mill}

A famosa Quarta Proposição decorre naturalmente das três primeiras. No entanto, essas últimas parecem envoltas em certo mistério, para quem não leu os Principles of Political Economy de Mill. Para que o leitor não se pergunte por que apenas nos referimos à Quarta Proposição sem fazer qualquer referência às três primeiras, vamos descrevê-las aqui. De certa forma, a quarta proposição é uma extensão lógica das três primeiras. Neste trabalho, Steven Kates, embora trabalhando com agregados e parecendo desconhecer a Teoria Austríaca do Capital e, por conseguinte, a TACE, mostra claramente que existe coerência interna entre as quatro proposições e também que o conjunto das quatro é uma ferramenta inestimável e coerente para a compreensão de uma economia de trocas. Trata-se de uma abordagem essencialmente neoclássica, mas esse fato não anula sua validade nem tampouco sua compreensão, desde que a reinterpretemos à luz dos elementos que compõem a TACE em seu conjunto. Neste artigo, no entanto, enfatizaremos a Quarta Proposição, já que estamos interessados em examinar o seu papel específico e a sua importância na TACE. É importante, contudo, deixar registrado que as quatro proposições são um resumo da posição dominante clássica prevalecente na época de Mill e, por- tanto, anterior ao livro seminal de Menger, o famoso The Principles of Political Economy, de $1871^{5}$.

Vejamos sucintamente os enunciados das três primeiras proposições:

Primeira Proposição:

"A indústria é limitada pelo capital" (e, adicionalmente, "todos os aumentos de capital proporcionam, ou são capazes de proporcionar, empregos adicionais na indústria, e isso sem um limite atribuível").

Segunda Proposição:

"O capital é o resultado da poupança".

Terceira Proposição:

"A poupança não é um abismo, um negativo, uma ausência, mas é uma utilização produtiva real dos recursos" (e, ainda, "o capital, embora poupado, é o "resultado" da economia e, não obstante, também é consumido)".

E a Quarta Proposição? Segundo o próprio Mill:

O que sustenta e emprega o trabalho produtivo é o capital despendido e destinado para o trabalho, e não a demanda dos compradores pelo produto do trabalho, quando concluído. Demanda de commodities não é demanda de mão de obra ${ }^{6}$.

Para a maioria dos economistas de hoje, entretanto, isto soa ou como incompreensível ou mesmo como absurdo, porque o keynesianismo sustenta como suposição básica exatamente o oposto. No mundo keynesiano, a demanda por mercadorias representa enfaticamente a demanda de mão de obra, embo-

${ }^{5}$ Disponível em português como MENGER, Carl. Princípios de Economia Política. São Paulo: Nova Cultural, 1988.

${ }^{6}$ MILL. The Principles of Political Economy. 
ra esta seja uma demanda derivada daquela. Esta suposição implícita de que adquirir mercadorias (ou quebrar vidraças, como escreveu Bastiat (1801-1850)) contribui para empregar trabalhadores - que a Escola Austríaca sempre rejeitou - é a que Mill estava tentando negar. Desejava demonstrar que comprar mercadorias não é o mesmo que empregar o fator de produção trabalho e que aumentos na demanda por mercadorias, ou seja, por bens de consumo, podem até mesmo fazer diminuir o número de pessoas empregadas. Precisamos entender como a lógica dessa proposição depende claramente da validade das três proposições anteriores. Este é nosso passo seguinte.

\section{III - A Coerência entre as Quatro Proposições de Mill}

Eis os vários degraus da lógica das quatro proposições fundamentais de Mill, conforme apresentados em um modelo diagramático bem simples, formulado e desenvolvido por Kates":

\section{Primeiro estágio}

Tomemos as duas primeiras proposições: $\left(1^{\underline{a}}\right)$ a indústria é limitada pelo capital; $\left(2^{a}\right)$ o capital é criado pela poupança.

Kates apresenta, para simplificar, uma Curva de Possibilidades de Produção em linha reta. No entanto, esse expediente não prejudica sua análise, porque as conclusões não se modificam com o seu relaxamento, ou seja, com a inclusão de curvas côncavas no sentido lato. No eixo vertical está a produção de mercadorias (bens de consumo ou de ordens menos elevadas para os austríacos) e, no horizontal, a produção de bens de capital (bens de ordens mais elevadas). O capital proporciona

${ }^{7}$ KATES, Steven. Mill's Fourth Proposition on Capital and Say's Law: Why the Demand for Commodities Really Isn't Demand for Labour. Disponível em: http://www.econrx.org/htdocs/hes/kates_mill_fourth_ proposition.pdf. a base para a produção, que pode ser sob a forma de bens de consumo ou de investimento, sendo que estes servem para aumentar o próprio estoque de capital. No gráfico 1 o produto se compõe de um montante $\mathrm{C} 1$ de bens de consumo (ou commodities) e um montante de capital I1. Notemos que $\mathrm{C}^{*}$ e $\mathrm{I}^{*}$ representam, respectivamente, o nível máximo de consumo que aconteceria quando o investimento fosse zero e o nível máximo de investimento caso o consumo fosse nulo. A distância entre $\mathrm{C}^{*}$ e $\mathrm{C} 1$ representa o montante de poupança, definida como a diferença entre o produto total e o consumo. A esse respeito, Mill escreveu que "consumir menos do que o montante produzido é poupar; e este é o processo mediante o qual o capital aumenta".

Correto, mas devemos lembrar, à guisa de parêntesis que, para os austríacos, no entanto, a poupança não é simplesmente a diferença entre produção e consumo - ou seja, entesouramento -, mas é determinada essencialmente pelas preferências intertemporais, em que a taxa de juros determina quanto vai ser consumido hoje e quanto de consumo será postergado para o futuro, ou seja, poupado hoje.

\section{Gráfico 1}

\section{Curva de Possibilidades de Produção - Consumo e Capital}

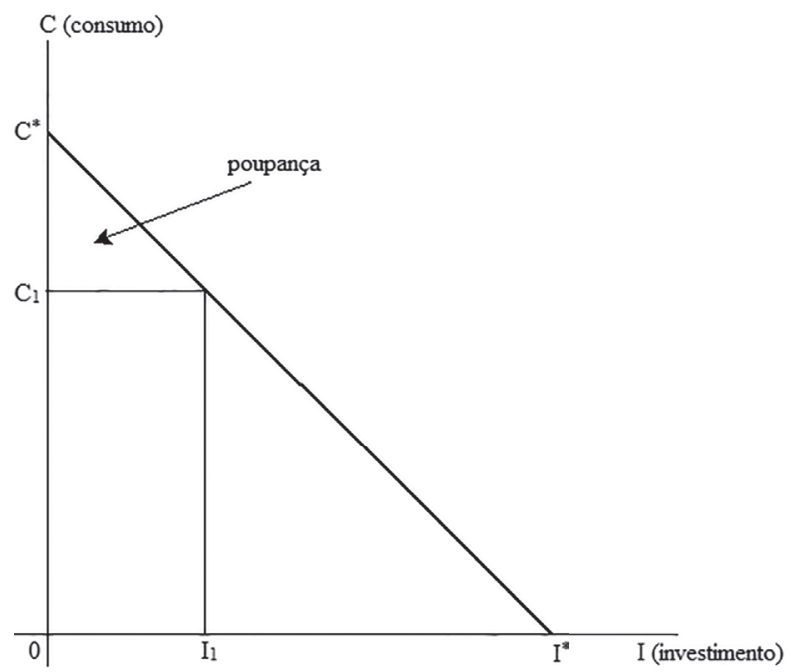

Vamos agora aumentar a demanda por bens de consumo para C2, como no gráfico 2 . 
Levando em conta que a capacidade da economia de produzir qualquer quantidade de produto é limitada por sua base de capital, esse aumento no consumo deve diminuir o nível de investimento, ou seja, a produção de bens de capital. Esse aumento na demanda por bens de consumo pode se dar ou por políticas de estímulo à demanda por esses bens ou por uma diminuição no desejo de poupar por parte dos agentes econômicos, como veremos no gráfico 9 mais adiante.

\section{Gráfico 2 \\ Curva de Possibilidades de Produção - Efeito de um Aumento no Consumo}

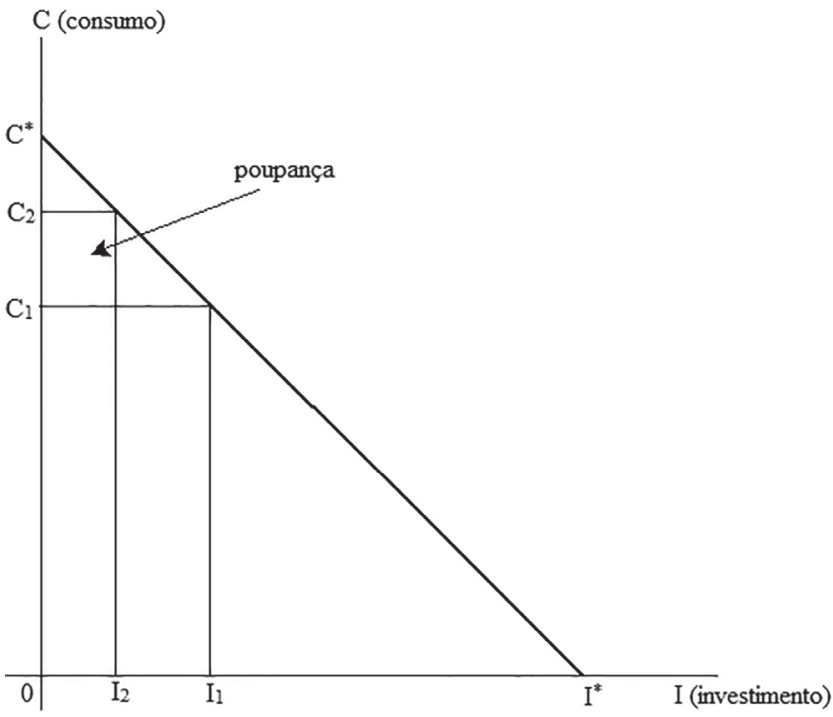

Como consequência - prossegue corretamente Kates - o desvio da produção de bens de capital para a produção de commodities vai diminuir a taxa de crescimento global da economia. Isso acontece porque o crescimento do capital, tanto em quantidade quanto em avanço tecnológico, produz impactos maiores sobre a capacidade de crescimento da economia do que o aumento na demanda por bens de consumo. Notemos que esse movimento para mais consumo e menos investimento tem um efeito imediato sobre a acumulação de capital, mas também um efeito de longo prazo, na medida em que a economia ficará restrita em sua capacidade de acumular capital por meio do crescimento do produto. Esse efeito poderia ser visto no gráfico como um deslocamen- to para a esquerda e para baixo na curva de possibilidades de produção, aproximando-a à origem dos eixos.

O aumento na demanda de mercadorias diminuiu a oferta de poupança, como se vê no gráfico 2 , de $C^{*}-\mathrm{C} 1$ para $C^{*}-\mathrm{C} 2$. Houve também uma queda equivalente na geração de capital (investimento), de I1 para I2. Com o passar do tempo, esse nível mais baixo de investimento significará que a capacidade de produzir tanto mercadorias como capital vai diminuir, restringindo novamente o crescimento do capital no longo prazo.

Existe uma relação positiva entre nível de investimento e montante de capital disponível na economia. Iso é retratado na figura 3: a consequência da queda no investimento (de I1 para I2 ) é uma diminuição na disponibilidade de capital (de K1 para K2).

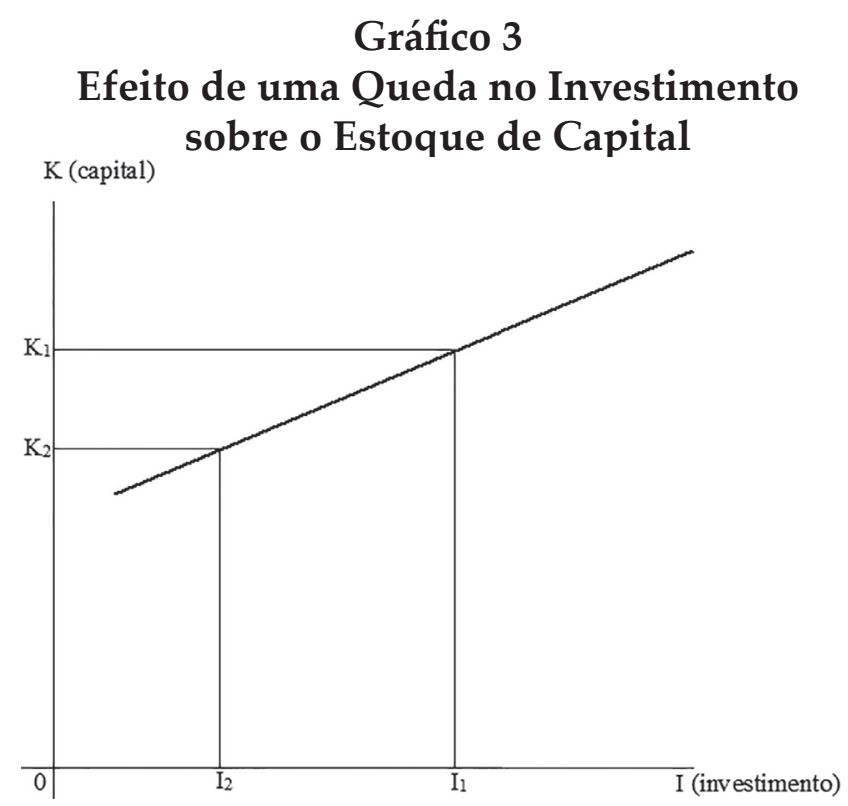

\section{Segundo estágio}

Mill está convencido de que não é a compra de bens e serviços que gera emprego, mas sim a sua produção, sua oferta. $\mathrm{O}$ que a demanda determina é o que deve ser produzido (notemos a harmonia dessa afirmativa com o pensamento de Menger e toda a tradição austríaca). Em suas próprias palavras:

A demanda de commodities determina em que ramo específico da produção o traba- 
lho e o capital devem ser empregados; ela determina a direção [prefeririamos dizer o sentido] do trabalho ${ }^{8}$.

É a decisão prévia de produzir, tomada por algumas empresas, o que determina o nível de produção e isso vai depender da quantidade de capital disponível. O produto é uma função crescente da oferta de capital. A quantidade de produto é determinada pela quantidade de capital, conforme mostra a figura 4.

Devemos notar, no entanto, a ausência nesta análise de um fator importantíssimo na Teoria Austríaca, que é a Estrutura de Capital da Economia (ou triângulos de Hayek). Com efeito, Mill e, por conseguinte, seu comentarista, o Prof. Kates, parece considerarem o capital como algo homogêneo e agregado, composto pelo estoque acumulado, até a data presente, de investimentos em máquinas, equipamentos, instalações e construções, ou seja, o capital físico.

Isto entra em choque flagrante com a análise austríaca - desenvolvida por Menger e aprofundada brilhantemente por Böhm-Bawerk, que trata o capital como uma estrutura bastante heterogênea ao longo dos diferentes estágios da estrutura de produção, desde os que produzem bens de capital (bens de ordens mais elevadas) até os que produzem bens consumo (ou bens de ordens baixas, sendo que os bens de consumo final, na nomenclatura adotada por Menger, ainda em 1871, são chamados de bens de primeira ordem. Para os austríacos, portanto - e isso é muito importante - o capital não se resume a máquinas e equipamentos, mas a todos os insumos que estão sendo utilizados nos diferentes estágios do processo de produção, aí incluída a mão de obra e o tempo de produção em cada estágio ou etapa desse processo.

\footnotetext{
${ }^{8}$ MILL. The Principles of Political Economy.
}

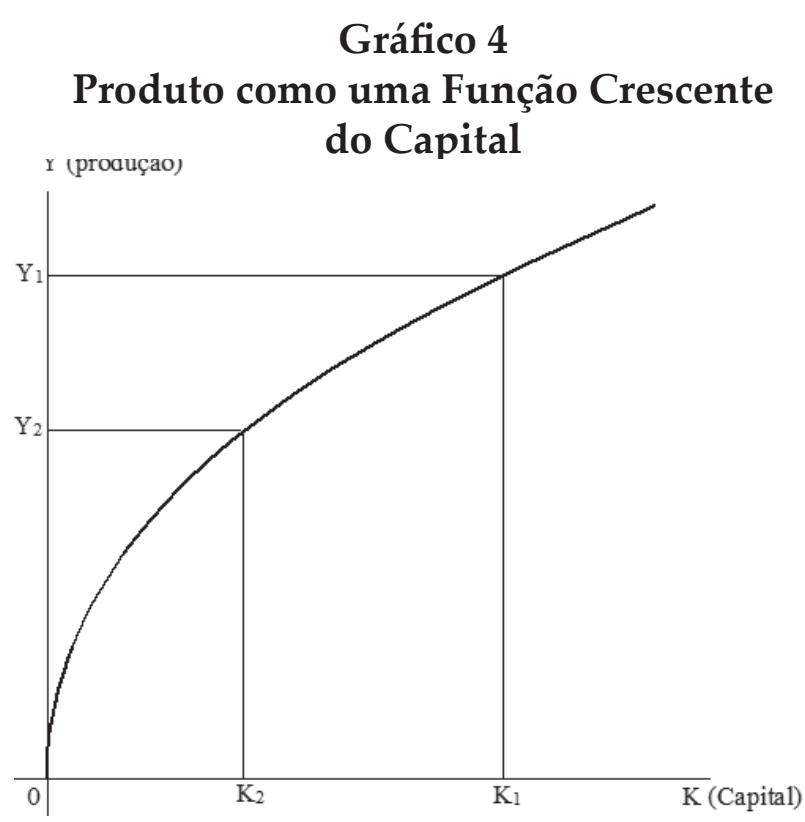

Com o nível de produção determinado pela quantidade de capital, uma queda nesta última geraria também uma queda no nível de produção. $\mathrm{O}$ desvio de esforço produtivo (investimento) para o consumo presente ocorrido no primeiro estágio diminuiu o montante de capital disponível. Essa diminuição no capital (de K1 para K2) traduz-se em uma queda correspondente no nível de produção (de Y1 para Y2). Em essência, isto está correto, mas não podemos deixar de lado o que escrevemos há pouco, isto é, que o capital não pode ser considerado um simples agregado, assim como o produto. Em outras palavras, essas quedas não são uniformes ao longo da estrutura de capital da economia.

\section{Terceiro estágio}

Neste estágio aparece o efeito da queda dos níveis de produção (de Y1 para Y2) sobre o nível de emprego. E aqui Mill acrescenta uma condição adicional, a de que os salários reais deveriam pelo menos ser mantidos:

Eu entendo que, se por demanda de trabalho se entende a demanda pela qual os salários aumentam, ou o aumento no número de trabalhadores no mercado de trabalho, a demanda de mercadorias não se constitui em demanda de trabalho?.

\footnotetext{
${ }^{9}$ MILL. The Principles of Political Economy.
} 
Com a queda no valor do capital puxando para baixo o salário médio real que pode ser pago, o efeito de uma queda na produção é uma queda na procura de trabalho ao nível atual do salário real. Uma vez que é a disponibilidade de capital no agregado o que importa - o que é muito mais do que apenas o "fundo de salários", pois inclui todo o

estoque de itens de capital que podem ser utilizados no processo de produção - a redução de capital se traduziu em uma redução na demanda por trabalho. Como Mill escreveu: "Cada adição ao capital dá para o trabalho: ou empregos adicionais ou remunerações adicionais", (assim como cada redução no capital deve ou reduzir o emprego de mão de obra ou levar a uma queda em sua remuneração).

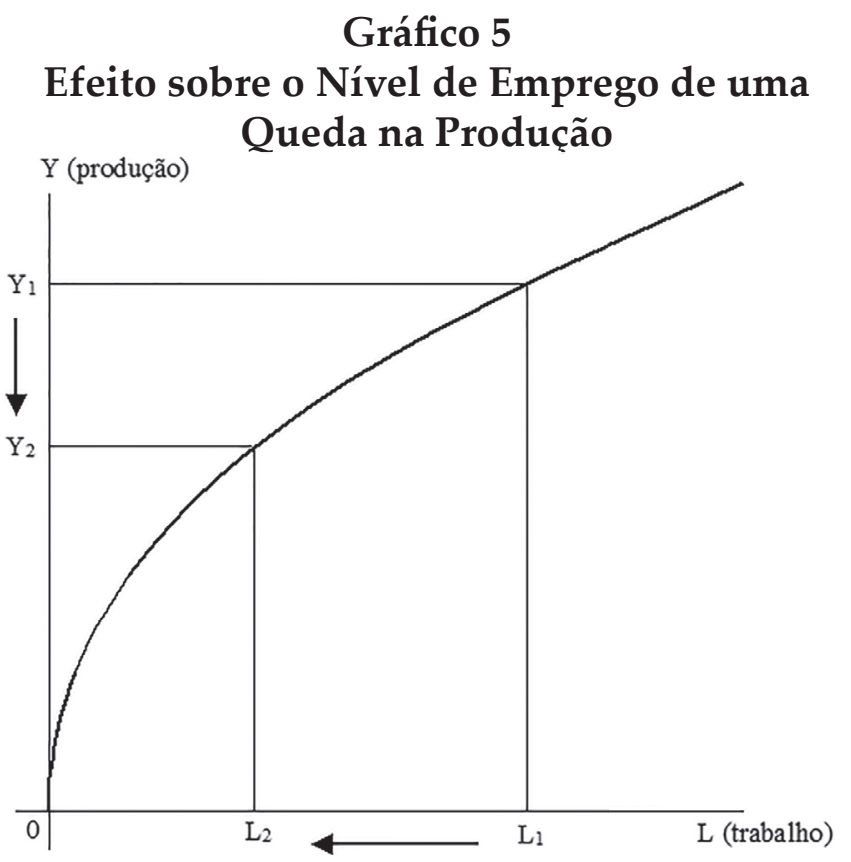

O gráfico 5 mostra uma função de produção com o nível de produto relacionado com o nível de emprego (é a famosa função de produção neoclássica). Vemos que a queda na produção de $Y 1$ para $Y 2$, mantido o salário real - ou seja, com a remuneração do trabalho mantida constante - provoca uma queda no nível de emprego de L1 para L2. Portanto, um aumento na demanda de consumo levou a uma queda no nível de emprego, contrariamente ao que o keynesianismo suporia mais de oitenta anos depois. Conclusão correta, mas que padece do mesmo defeito apontado anteriormente: não é correto, na concepção austríaca, tratar a mão de obra, o consumo e o emprego de mão de obra como agregados, já que, como a produção é composta por estágios, em cada um destes haverá um mercado de trabalho específico, com oferta e demanda e as quedas não serão unigormes, pelo contrário, serão desiguais ao longo da estrutura austríaca de produção, pela combinação dos efeitos Ricardo e preços relativos.

Efeitos de aumentos na demanda de mercadorias (consumo presente)

Este modelo sugerido por Kates é coerente e internamente consistente, no contexto neoclássico, para representar a economia descrita pelas três primeiras proposições de Mill sobre o capital. A Quarta Proposição segue, como já escrevemos, da compreensão das três primeiras. Ela mostra que um aumento na demanda de mercadorias (consumo presente) levaria a uma queda na demanda por mão de obra, porque desviaria a utilização de recursos da criação de capital adicional - e é apenas a quantidade de capital que suporta maior emprego. Uma queda na quantidade de capital produzido levaria a uma queda no valor de produção e, portanto, a uma redução no nível de emprego, para que os salários reais pudessem ser mantidos constantes. Aqui devemos salientar que essa diminuição na demanda de mão de obra não se dará em todos os estágios da estrutura de produção, mas apenas naqueles que produzem bens de ordens mais elevadas, distantes, portanto, do consumo final.

No entendimento da noção de commodities, é claro que Mill refere-se ao uso da base de recursos de uma economia para produzir formas de produto não geradoras de crescimento. Estas são formas de produção que não fornecem uma base para aumentar o nível de emprego. Para Mill, a produção de bens e serviços não utilizados para agregar valor ao estoque total de capital, ou como insumos em uma empresa produtiva, mas sim como mercadorias para serem vendidas em um arma- 
zém, ou como bens e serviços comprados pelos assalariados, não podem aumentar o nível de emprego ao salário real existente.

E este é o ponto de Mill, na concepção neoclássica. Foi uma conclusão que satisfez toda uma geração de economistas e é difícil ver de que forma ela estaria realmente errada. É certamente um argumento válido em seus próprios termos e contexto. É sempre possível aumentar o emprego ao mesmo tempo, se o salário real médio cair. Mas se o objetivo da política é manter ao mesmo tempo o emprego e tornar a comunidade mais próspera, então o foco deve ser na acumulação de capital em seu sentido mais amplo, o que significa que esse conceito deve incluir as mudanças tecnológicas e, possivelmente, até o desenvolvimento de habilidades (capital humano, um conceito que não era conhecido por esse nome na época). Apesar de os austríacos discordarem de políticas econômicas, essa conclusão de Mill não anula o fato elementar de que a essência do crescimento econômico é a acumulação de capital, que acontece mediante investimentos (e não por estímulos ao consumo presente). Vidraças quebradas só oferecem ganhos para vidraceiros e para a indústria de vidros.

Resumindo a Quarta Proposição: um aumento na demanda de consumo desvia esforços produtivos da acumulação de capital e, portanto, das formas de produção que podem suportar ou apoiar o nível de emprego. Demanda de mercadorias não é demanda de trabalho.

\section{IV - Críticas de Kates a Hayek e a Resposta Austríaca}

Segundo Kates, há três interpretações simpáticas a Mill, mas equivocadas no seu modo de entender. Kates sugere ser instrutivo lançar um olhar mais atento a essas discussões mais importantes da Quarta Proposição de Mill, em que o comentarista declarou concordância inicial, mas depois mostrou desacordo fundamental. Nossa atenção aqui estará dirigida, logicamente, a Hayek, mas apenas para conhecimento do leitor, cabe dizer que os outros dois são Alfred Marshall (18421924) e Allyn Young (1876-1929). Para Kates, quando cada um deles tenta mostrar concordância com Mill, no final, "são incapazes de compreender o que Mill tentou dizer". Nosso propósito é mostrar que, pelo menos no que diz respeito a Hayek, isto não é verdadeiro.

Sobre Hayek, podemos resumir a crítica de Kates: Hayek fornece uma avaliação mais completa em sua Teoria Pura do Capital ${ }^{10}$. Como Alfred Marshall, sua discussão está em um anexo do texto principal e, outra vez como Marshall, Hayek vê a quarta proposição de Mill sendo "naturalmente intimamente ligada com a teoria do fundo de salários" 11 . Mas, então, Hayek, na tentativa de explicar o significado de Mill, começa por reinterpretar o que Mill realmente disse:

Antes de prosseguir, no entanto, será aconselhável a restabelecer a proposição de Mill de uma forma que não deixa dúvidas sobre o seu significado exato. Em primeiro lugar, é provavelmente claro que o modo como a doutrina tem sido geralmente colocada precisa ser corrigido, como temos feito, para substituir "commodities" por bens de consumo e que a demanda de "commodities" terá de ser descrita não como uma simples quantidade, mas como uma demanda ou curva que descreve as quantidades de bens de consumo que serão comprados a preços diferentes. Em segundo lugar, o teste para saber se a demanda por "bens" dos consumidores é "demanda por trabalho" (ou, podemos dizer, demanda pura por inputs) deve ser claramente se um aumento na curva de demanda por bens de consumo aumenta a curva de demanda por inputs (e se uma queda da primeira reduz a última), ou se uma alteração na demanda dos consumidores de bens não causa mudança na mesma direção, ou talvez mesmo, uma mudança na direção uma mudança na direção oposta, para a demanda pura por inputs.

${ }^{10}$ HAYEK, F. A. The Pure Theory of Capital. Auburn, Alabama: The Ludwig von Mises Institute, 2009 [1941]. p. 433-39.

${ }^{11}$ Idem. Ibidem, p. 433. 
Aí parece claro que Hayek tinha em mente a estrutura de capital que caracteriza a Escola Austríaca.

Este é o ponto de Hayek. Do modo como interpretou o efeito-Ricardo (não como a simples substituição de homens por máquinas e sim por substituições entre bens de ordens mais elevadas por bens de ordens menos elevadas ao longo da estutura de capital), a Quarta Proposição de J. S. Mill significa que consumo e investimento, definidos não como agregados, mas compartimentalizados em estágios, podem e devem normalmente variar em sentidos opostos.

Hayek interpreta o aforismo da Quarta Proposição ("demanda de mercadorias não é demanda de trabalho"), sugerindo que Mill procurava enfatizar que é precipitado incorporar demandas derivadas em economia política e tirar conclusões a esmo. As teorias macroeconômicas modernas, em que as demandas pelo produto final e pelos fatores de produção movem-se sempre no mesmo sentido, parecem não dar importância a essa advertência. Esta é a Quarta Proposição de Mill segundo Hayek.

Para Kates, ambas essas reinterpretações afastam-se de Mill. Relacionar mercadorias com bens de consumo não é muito certo, segundo ele. Commodities para Mill são bens que são consumidos no presente sem deixar renunciar a um ambiente econômico mais produtivo (?) [interrogação nossa]. Não são apenas os consumidores finais que podem fazer isso, mas os governos também (?) [idem], bem como, e em algumas circunstâncias, empresas. E em segundo lugar, Hayek transfere o significado da demanda de mão de obra para a "demanda pura por inputs", que para ele significa muito mais do que apenas trabalho, pois inclui todas as formas de contribuição para o processo de produção. Kates interpreta que o ponto crucial que Mill estava tentando ressaltar sobre a relação entre a disponibilidade de capital e e nível de emprego, portanto, desaparece imediatamente.

Na verdade - prossegue Kates - "é pior".

Tem havido algum debate sobre os anos em que Hayek não tinha respondido à Teoria Geral imediatamente após a publicação. A razão pode, de fato, ser que, tanto quanto o ponto principal com que Keynes estava preocupado, ele e Keynes estavam em completo acordo. Mill tinha tentado argumentar que a demanda por bens e serviços não levaria a um aumento do emprego. Hayek, no entanto, concordou com Keynes que, em tempos de alto desemprego, aumento da demanda levaria a uma maior emprego.

Ainda seguindo Kates, agora citando literalmente Hayek:

$\mathrm{O}$ fato de que em condições de sub-emprego o princípio geral de Mill não se aplica diretamente foi, naturalmente, bem conhecido pelos "economistas ortodoxos" e por J. S. Mill em particular. Em sua exposição a afirmação de que a indústria "está limitada pelo capital", em que, como vimos, a proposta em discussão é baseada, imediatamente seguido pela declaração de que "nem sempre vai até esse limite". E alguns economistas competentes podem nunca ter duvidado de que, em posições de desequilíbrio em que há reservas não utilizadas de recursos de todos os tipos, a operação deste princípio é temporariamente suspensa, embora eles possam nem sempre ter dito isso ${ }^{12}$.

Em outras palavras, para Kates, quando há recursos não utilizados, a demanda por commodities constitui-se em demanda de trabalho. A partir disto, a conclusão a que chega Hayek é bastante diferente da de Mill:

Mais do que nunca, parece-me ser verdade que a compreensão completa da doutrina de que "a demanda de commodities não é a demanda por mão de obra" - e de suas limitações - é "o melhor teste para um economista".

Como podemos inferir da teoria austríaca, não há qualquer "afastamento" de Mill: os austríacos, desde Menger em 1871, de Mises em 1912 e de Böhm-Bawerk, sempre trabalharam com o conceito de Estrutura de Capital

\footnotetext{
${ }^{12}$ Idem. Ibidem, p. 439.
} 
(ou Estrutura Mengeriana de Produção ou Triângulos de Hayek).

Uma estranha conclusão, segundo Kates, dado que Mill tinha considerado esta uma de suas proposições fundamentais sobre o capital. Não poderia ter sido inteiramente fundamental se contivesse os tipos de "limitações" que Hayek descreveu. Nada de "estranho" - rebatemos - desde que se considere o capital como uma estrutura heterogênea.

\section{V - A Quarta Proposição e a TACE}

Acabamos de ver, embora ligeiramente, que, com seu conhecido aforismo "demanda de mercadorias não é demanda de trabalho", Mill procurava ressaltar o perigo da incorporação de demandas derivadas em economia política. As teorias macroeconômicas modernas, em que as demandas pelo produto final e pelos fatores de produção movem-se sempre no mesmo sentido, parecem não dar importância à advertência de Mill e muito menos às dos austríacos, aqui representados por Hayek.

Assim, na conhecida equação de corte keynesiano $\mathrm{Y}=\mathrm{C}+\mathrm{I}$, em que $\mathrm{Y}$ representa o produto "agregado", C o consumo "agregado" e I o investimento "agregado", se um dos componentes da demanda ( $\mathrm{C}$, por exemplo) estiver subindo (caindo), então o outro (I, no caso), necessariamente, também estará subindo (caindo). Essa suposição - a nosso ver, equivocada - é base para todo o keynesianismo, com seu conhecido efeito multiplicador.

A formulação austríaca reconhece que as duas demandas podem mover-se em sentidos opostos e essa atenção para com a Quarta Proposição daquele economista inglês do século XIX (de quem Hayek era um admirador) é uma das diferenças mais significativas entre a teoria dos ciclos austríaca - TACE - e suas rivais.

Na verdade, a quarta proposição de Mill serve para distinguir a "macroeconomia" de Hayek - e, por conseguinte, a Escola Austríaca - da macroeconomia keynesiana e Hayek explicitamente reconheceu a importância fun- damental desta proposição, ainda nos anos 1920, antes, portanto, do surgimento real do keynesianismo.

Se o consumo presente está caindo, isto não significa necessariamente que a demanda de trabalho e de outros fatores também esteja caindo: pode significar que a propensão a poupar esteja aumentando e, portanto, que o consumo futuro também vai crescer, o que, se for incorporado às expectativas dos produtores, poderá fazer crescer a produção de bens de consumo futuros e, assim, aumentar a demanda de trabalho no período atual. Para Hayek, em um dado período, os gastos de consumo e de investimento podem e, em condições de pleno emprego (ou de nível natural de emprego), devem mover-se em sentidos contrários.

Da mesma forma, se o consumo está aumentando (como consequência, por exemplo, de uma disposição menor a poupar), isto não significa automaticamente que a demanda de trabalho e de outros insumos componentes da Estrutura de Capital esteja também subindo: pode significar que o desejo de poupar esteja caindo e que, portanto, o consumo futuro também vai cair - porque a formação de capital vai declinar e não será lastreada na poupança, que diminuiu -, o que, quando incorporado às expectativas dos produtores, poderá diminuir a demanda de trabalho imediatamente.

$\mathrm{Na}$ verdade, este deslocamento de recursos entre bens de ordens inferiores ("consumo") e bens de ordens superiores ("investimento") e entre os diversos estágios da estrutura de produção - os efeitos Ricardo, preços relativos, taxas de juros e concertina - é que leva à coordenação intertemporal ou à sua ausência: coordenação, quando o deslocamento é provocado por alterações nas preferências temporais e falta de coordenação quando é causado por manipulações monetárias, por crédito não lastreado em poupança.

Vale novamente enfatizarmos que a demanda por fatores de produção é estritamente uma demanda derivada e, embora não haja qualquer objeção à noção de demanda derivada no âmbito microeconômico de análise de 
equilíbrio parcial, extrapolar, como fez Keynes, da empresa ou da indústria para a economia como um todo e afirmar que a demanda da economia por mão de obra é derivada à la Marshall da demanda por bens de consumo é incorrer na conhecida falácia da composição, que consiste em se admitir que o que é verdade para uma parte do sistema, então também é verdade para todo o sistema. Observamos que isso nos leva à própria macroeconomia. Por exemplo, se a quantidade de pães fabricados por um trabalhador em uma padaria for muito elevada num determinado dia, o rendimento dos seus colegas aumentará, embora a produção dos mesmos possa até ter sido menor naquele dia; porém, se todos os trabalhadores na padaria conseguirem produzir quantidades muito grandes de pães, o rendimento do conjunto poderá ser mais baixo. Se concluíssemos o contrário, incorreríamos na falácia da composição.

A teoria keynesiana, no entanto, não se restringe à demanda por bens de consumo, mas a todas as formas de gastos: quanto maior a demanda agregada, maior a demanda por mão de obra. Este é o ponto fundamental da análise do tipo $\mathrm{C}+\mathrm{I}+\mathrm{G}+\mathrm{X}-\mathrm{M}$, sintetizado no início dos anos 40 por Alvin Hansen (18871975) e John Hicks (1904-1989) nas famosas "curvas IS e LM". Adicionalmente, de acordo com Mill, qualquer homem que não seja um débil mental intui que aumentos na demanda por bens de consumo não aumentarão por si próprios a demanda de trabalho.

O Professor Roger Garrison, da Auburn University, em resenha ao livro Money, Capital, and Fluctuations: Early Essays ${ }^{13}$, observa que em dois dos ensaios contidos no livro - Intertemporal Price Equilibrium and Movements in the Value of Money, de 1928, e Capital Consumption, de 1932 - Hayek aprofunda a integração da teoria austríaca do valor com as teorias monetárias de Knut Wicksell e de Ludwig von Mises.

13 HAYEK, F. A. Money, Capital and Fluctuations: Early Essays. Chicago: The University of Chicago Press, 1984.
No contexto macroeconômico, podemos conceber toda a economia como um conjunto de atividades de consumo e atividades de investimento. Portanto, dada a fronteira de possibilidades de produção, ou seja, abstraindo-nos da questão do crescimento econômi$\mathrm{co}$, que tem o efeito de deslocar essa fronteira para cima e para a direita, um aumento em um desses dois componentes deve ser acompanhado de uma diminuição no outro. Para a economia como um todo, o nível de gastos de consumo e do nível de despesas de investimento devem mover-se em direções opostas. Hayek reconhece claramente essa relação e esse reconhecimento viria a se tornar básico para suas críticas a Keynes, cuja teorização desprezou a Quarta Proposição de Mill, já que, na visão de Keynes, isto se daria apenas no caso especial e improvável de uma economia no pleno emprego.

Embora tenha colocado em seu livro mais famoso o título de "Teoria Geral", Keynes, na verdade, em termos metodológicos, lidou apenas com um caso especial, o de ociosidade de recursos. Conforme nota Garrison, consumo e investimento podem se mover no mesmo sentido apenas quando o nível de ociosidade de recursos se move no sentido oposto. Não há custos de oportunidade (ociosidade passada não é um custo) associados a ter mais de ambos os componentes da atividade econômica. Com efeito, foi o desprezo de Keynes em relação à Quarta Proposição de Mill que levou Hayek a se referir à economia keynesiana como "economia da abundância".

No ensaio de 1928, Hayek mostra como o mecanismo de preços relativos do mercado desloca recursos das atividades de consumo para atividades de investimento em resposta a mudanças nas preferências intertemporais dos consumidores. Ele mostra como uma queda na demanda de produtos (isto é, no consumo corrente), pode ser associada com um aumento na demanda de trabalho e outros inputs no espectro temporal da estrutura de produção, permitindo assim um aumento no nível de consumo futuro. Estes são os mecanismos de mercado, cuja existência ou 
é negada ou ignorada ou negligenciada por Keynes.

Eis a essência da TACE: com taxas de juros artificialmente baixas, os consumidores reduzem a poupança e passam a consumir mais, e os empresários aumentam seus gastos com investimento. E então se cria um desequilíbrio entre poupança e investimento. Tem-se uma economia com crescimento insustentável. Essa é, em suma, a lição da crítica austríaca aos bancos centrais, desenvolvida nos anos 1920 e 1930.

Com bastante clareza, o Prof. Garrison observa que, quando as pessoas optam por poupar mais, mandam dois sinais aparentemente conflitantes para o mercado: o primeiro é que consumo menor enfraquece a demanda por bens de capital que estão próximos - em termos temporais - do produto final de consumo. Esse é o efeito derivado da demanda. E o segundo é que uma taxa de juros menor, que significa empréstimos a custos menores, estimula a demanda por bens de capital que estão distantes, em termos temporais, do produto final de consumo. Esse é o efeito do desconto temporal - ou simplesmente o efeito da taxa de juros.

Os efeitos derivados da demanda e do desconto temporal estarão em conflito apenas se o "investimento" for concebido como um simples agregado - como é na fórmula keynesiana C + I + G. Na macroeconomia baseada no capital, ou seja, na Escola Austríaca, o capital - logo, o investimento - é concebido como uma estrutura. Mudanças na demanda por investimentos, portanto, produzem efeitos distintos sobre os vários estágios da produção (que podem sofrer adições ou subtrações) que compõem a estrutura de capital.

A teoria de Keynes, que foi feita em termos de agregados, negligenciando não só a teoria austríaca do capital, mas qualquer outra teoria do capital deu motivos para a afirmação de Hayek de que "os agregados do Sr. Keynes escondem os mecanismos mais fundamentais da mudança".

Um aumento na poupança resulta em uma realocação de recursos entre os estágios da produção. Os dois efeitos (o derivado da demanda e o desconto temporal) atuam separada e complementarmente na estrutura de capital.

Pelo efeito derivado da demanda, uma diminuição da demanda por bens de consumo desestimula os investimentos nos estágios finais da produção, reduzindo a altura do triângulo hayekiano e, pelo efeito do desconto temporal, uma taxa de juros reduzida estimula os investimentos nos estágios iniciais da produção, aumentando a base do triângulo hayekiano.

Aumentos na poupança, portanto, têm efeito tanto na magnitude do investimento quanto no padrão temporal da criação de capital. A FPP mostra que mais poupança permite mais investimento. $\mathrm{O}$ triângulo hayekiano mostra que a criação de capital nos últimos estágios da produção (tais como estoques varejistas) diminui, ao passo que a criação de capital nos estágios iniciais (tais como desenvolvimento de produtos) aumenta.

A estrutura da produção passa a ter uma orientação mais voltada para o futuro, o que é consistente com a poupança, o elemento que tornou possível tal reestruturação. Ou seja, as pessoas estão poupando agora para aumentar seu poder de compra futuro. U m aumento na poupança tem efeitos diferenciados na demanda por mão de obra nos estágios iniciais e finais. Nos estágios finais, o efeito derivado da demanda (o investimento se dá em detrimento do consumo) supera o efeito da taxa de juros. Nos estágios iniciais, o efeito da taxa de juros (condições creditícias favoráveis) supera o efeito derivado da demanda.

A Escola Austríaca não trata o mercado de trabalho como um todo, mas especifica um mercado de trabalho para cada um dos estágios da estrutura de produção. Com alterações na taxa de juros, logicamente os salários específicos por estágio se alteram seguindo um padrão, e não uniformemente. A esse respeito, embora fosse possível especificar um mercado de trabalho para cada estágio da estrutura de capital, a característica das mudanças (ou gradiente salarial, nas palavras de 
Hayek), só é revelado se distinguirmos entre os mercados de trabalho do estágio inicial e final, conforme a figura 6 nos mostra.

\section{Gráfico 6}

Mercado de Trabalho por Estágios da Estrutura de Capital

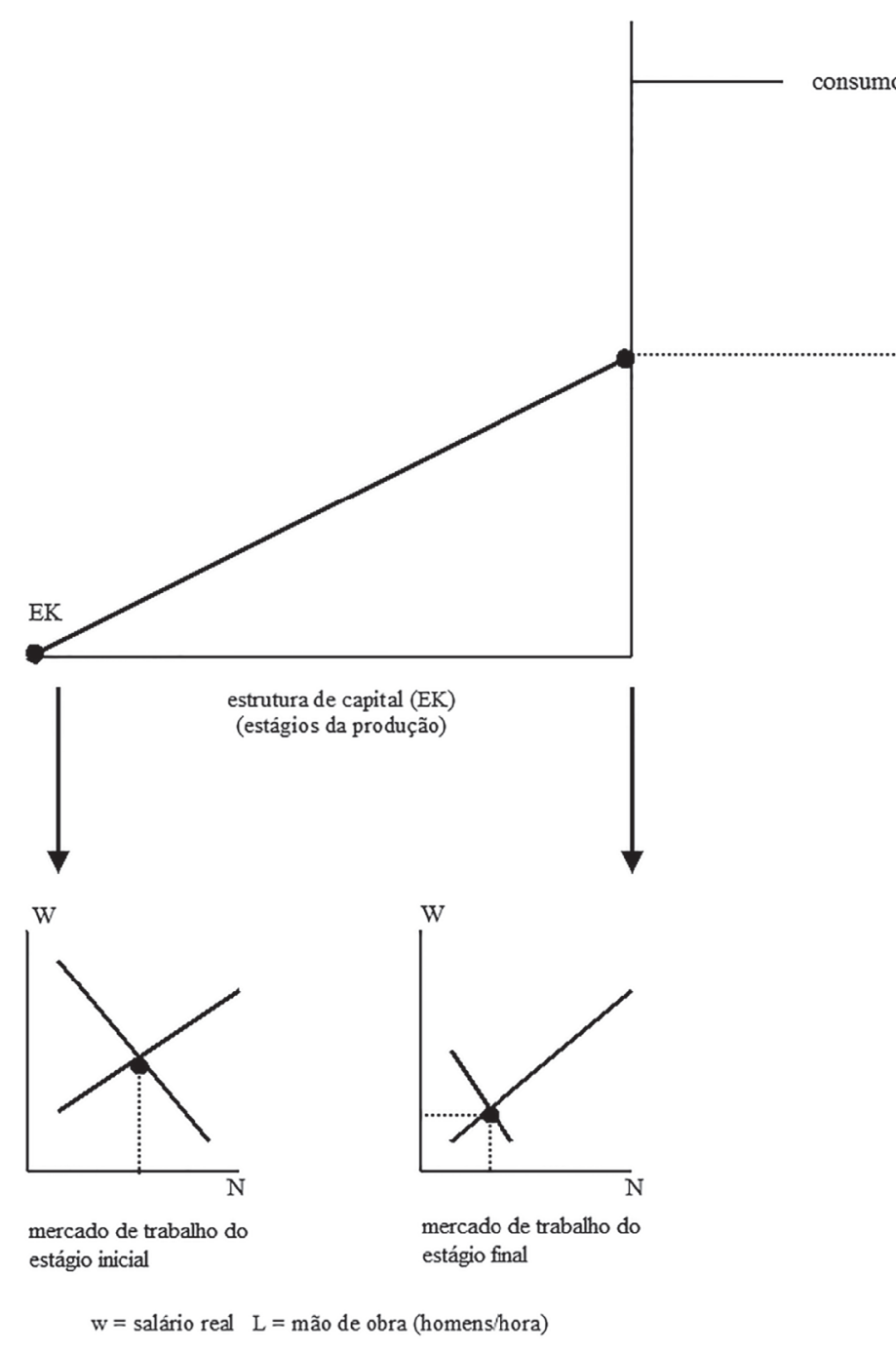

Notemos agora que aumentos na poupança produzem efeitos diferenciados na demanda de trabalho nos estágios iniciais e finais: nos primeiros, o efeito da taxa de juros ou seja, condições de crédito mais favoráveis -, é mais forte do que o efeito derivado da demanda, enquanto nos estágios finais o efeito derivado da demanda, em que o aumento no investimento se dá em contraposição a uma queda do consumo, supera o efeito da taxa de juros. Isto pode ser visualizado na figura 7 , em que a demanda de mão de obra aumenta no estágio inicial, levando a um crescimento no salário real, ao mesmo tempo em que no estágio final (de bens de consumo final), ela cai, reduzindo o salário real.

Esta conclusão lógica nada mais é do que a Quarta Proposição de Mill na interpretação austríaca.

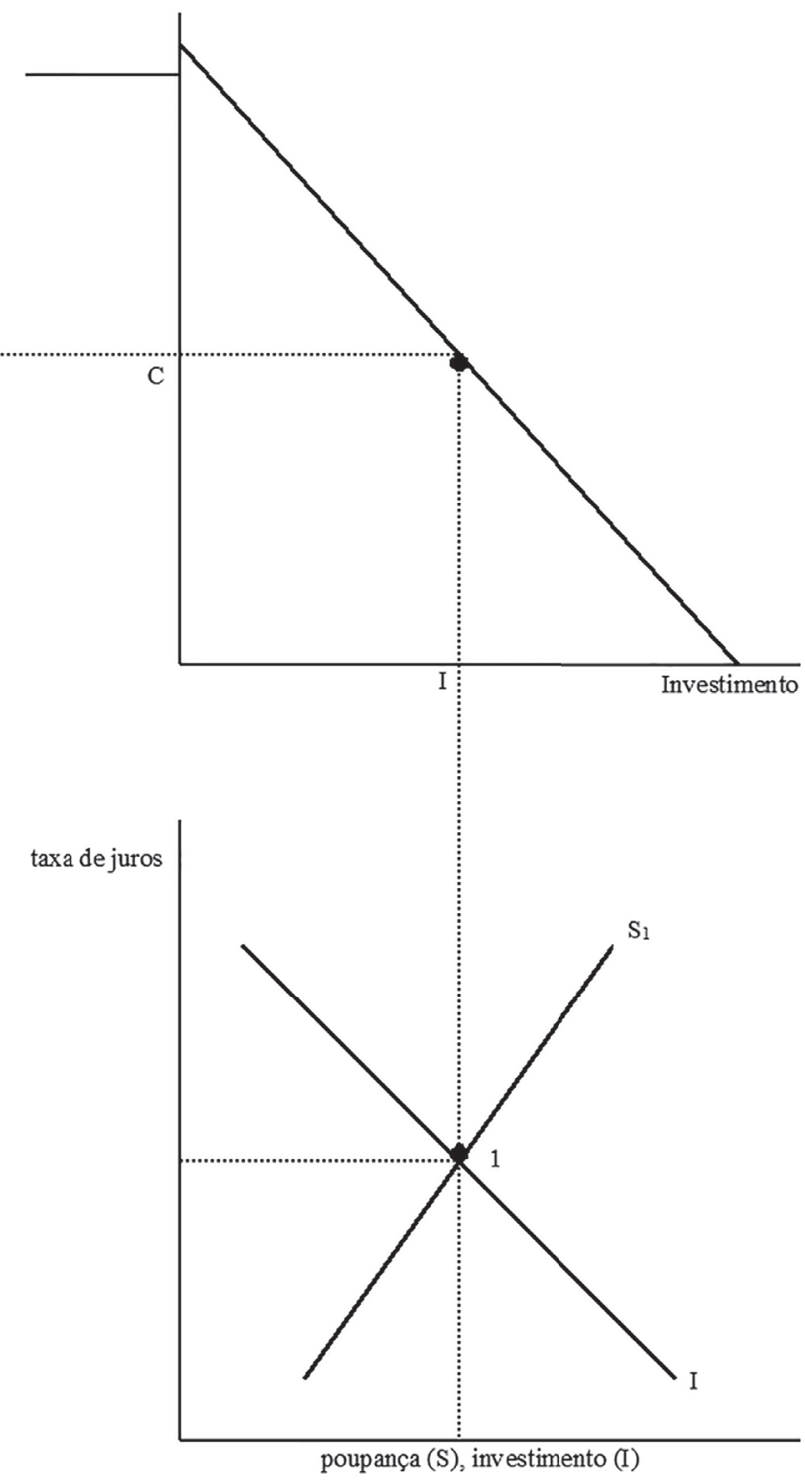

Quando a economia cresce de forma sustentada, vale dizer, escorada em uma disposição dos agentes de pouparem mais no presente e, por conseguinte, adiarem o consumo, os triângulos hayekianos aumentam de tamanho, correspondendo a expansões da fronteira de possibilidades de produção. Isto é visto no gráfico 7 .

Com o aumento da formação de capital da economia, tanto a fronteira de possibilida- 
des de produção como a estrutura de produção deslocam-se para cima: o consumo menor enfraquece a demanda por bens de capital que estão próximos - em termos temporais - do produto final de consumo. Esse é o chamado efeito derivado da demanda. Por outro lado, a menor taxa de juros agora vigente, vale dizer, empréstimos a custos menores, estimula a demanda por aqueles bens de capital afastados dos bens finais de consumo, na estrutura de produção Esse é o efeito do desconto temporal ou o efeito da taxa de juros.

Mas esses dois efeitos só estarão em conflito se o "investimento" for concebido como um simples agregado, tal como na abordagem keynesiana. Na "macroeconomia" austríaca que trabalha com uma estrutura de capital o investimento é tratado como uma estrutura. Logo, alterações na demanda por investimentos costumam produzir efeitos distintos sobre os vários estágios da produção (que podem sofrer adições ou subtrações) que compõem a estrutura. Temos, novamente, a Quarta Proposição de Mill.

\section{Gráfico 7 \\ Crescimento Sustentado (Lastreado em Poupança Genuína)}

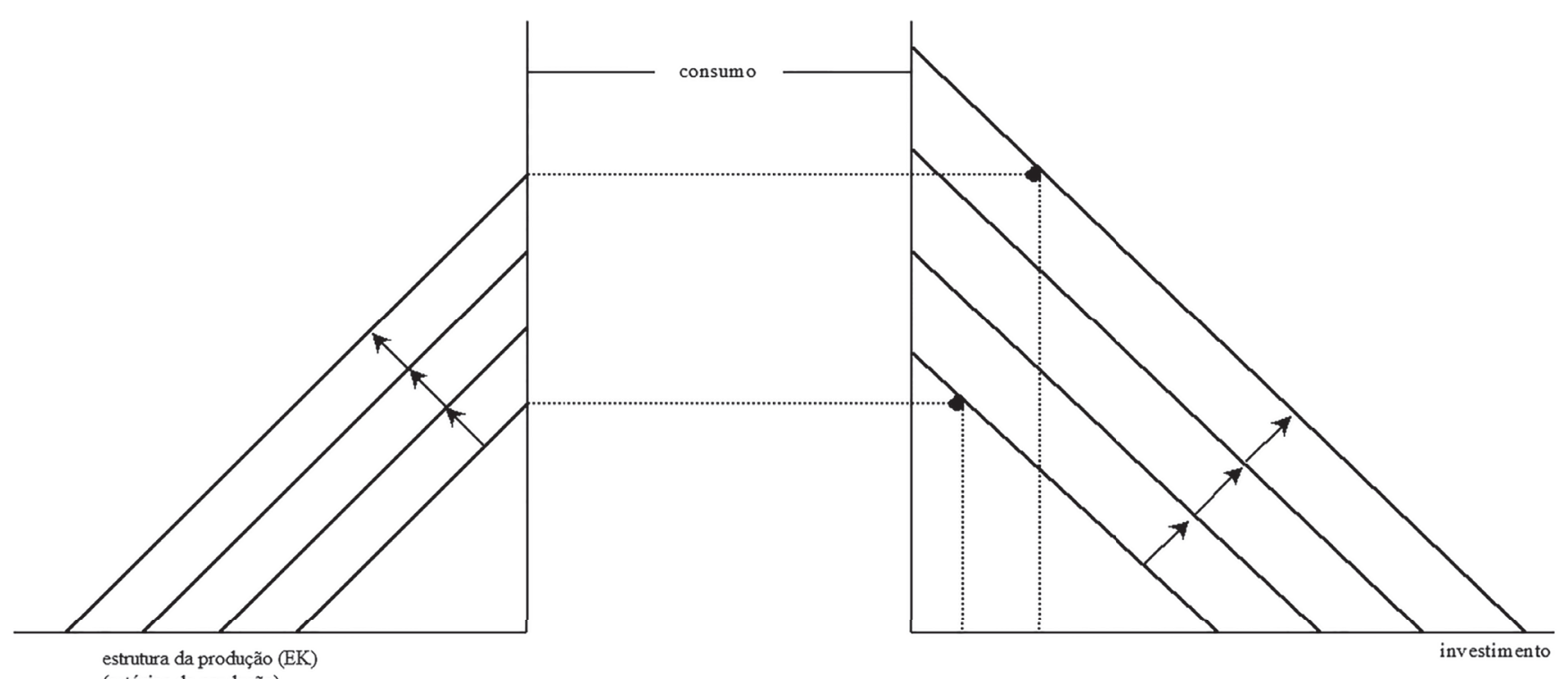

Para reforçarmos como a Quarta Proposição é importante na TACE, vejamos dois casos, opostos e simétricos, o da maior e o da menor disposição de poupar, que aparecem nos gráficos 8 e 9 .

No gráfico 8, um aumento na poupança resulta em uma realocação de recursos entre os estágios da produção. Os dois efeitos (o derivado da demanda e o desconto temporal) atuam separada e complementarmente na estrutura de capital. Pelo efeito derivado da demanda, a diminuição da demanda por bens de consumo desestimula os investimentos nos estágios finais da produção, reduzindo a altura do triângulo hayekiano. E o efeito do desconto temporal dá-se porque uma taxa de juros reduzida estimula os investimentos nos estágios iniciais da produção (por aumentar os valores presentes de seus projetos de investimento comparativamente aos valores presentes dos projetos de investimentos dos estágios mais próximos dos bens de consumo final), aumentando a base do triângulo hayekiano.

A estrutura da produção passa a ter uma orientação mais voltada para o futuro, o que é consistente com a poupança genuína que tornou possível tal reestruturação. Ou seja, as pessoas poupam agora para aumentar seu poder de compra futuro. Embora o consumo presente diminua, ele certamente

voltará a crescer a uma taxa maior, assim que a economia se adaptar à nova taxa de crescimento, que será maior porque os in- 
vestimentos que foram feitos eram lastreados em poupança. Assim, poupar mais hoje significa poder consumir mais no futuro, tal como no gráfico 7 que explicamos linhas atrás, que mostra os efeitos de longo prazo dessa disposição maior de poupar.

\section{Gráfico 8 \\ Efeitos de Aumentos na Poupança}

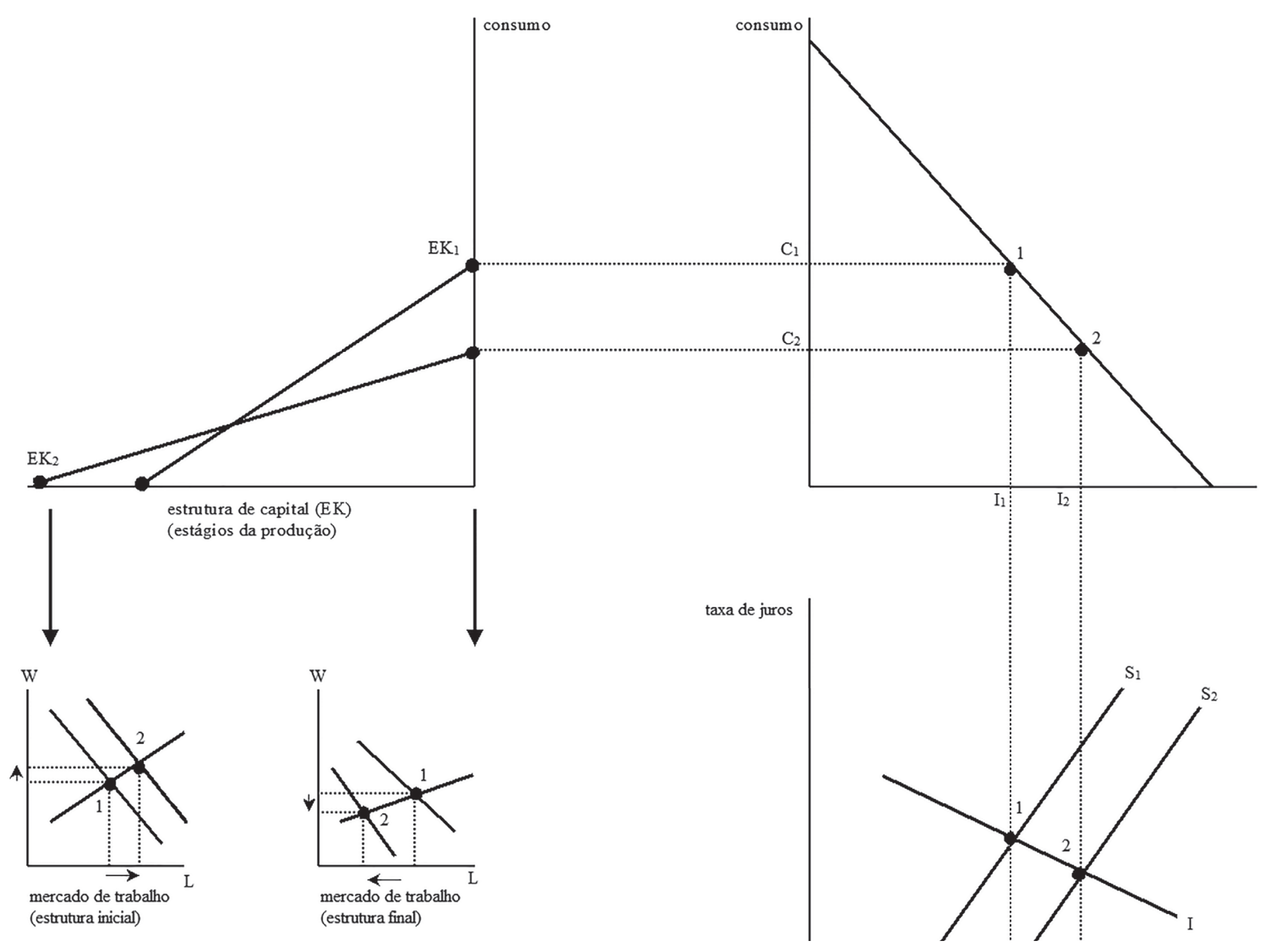

nos estágios iniciais e finais: nos primeiros, o efeito taxa de juros - ou seja, condições de crédito mais favoráveis -, é mais fraco do que o efeito derivado da demanda, enquanto nos estágios finais o efeito derivado da demanda, em que o aumento no investimento se dá em contraposição a uma queda do consumo, é superado pelo efeito taxa de juros. Isto pode ser visualizado na figura 9, em que a deman-
E o que dizer de mudanças nas preferências intertemporais que reduzem o desejo de poupar e, portanto, aumentam a demanda de bens de consumo presente? Notemos agora que a queda na poupança produz também efeitos diferenciados na demanda de trabalho da de mão de obra diminui no estágio inicial, levando a uma queda no salário real, ao mesmo tempo em que no estágio final (de bens de consumo final), ela sobe, aumentando o salário real. 


\section{Gráfico 9 \\ Efeitos de Quedas na Poupança}

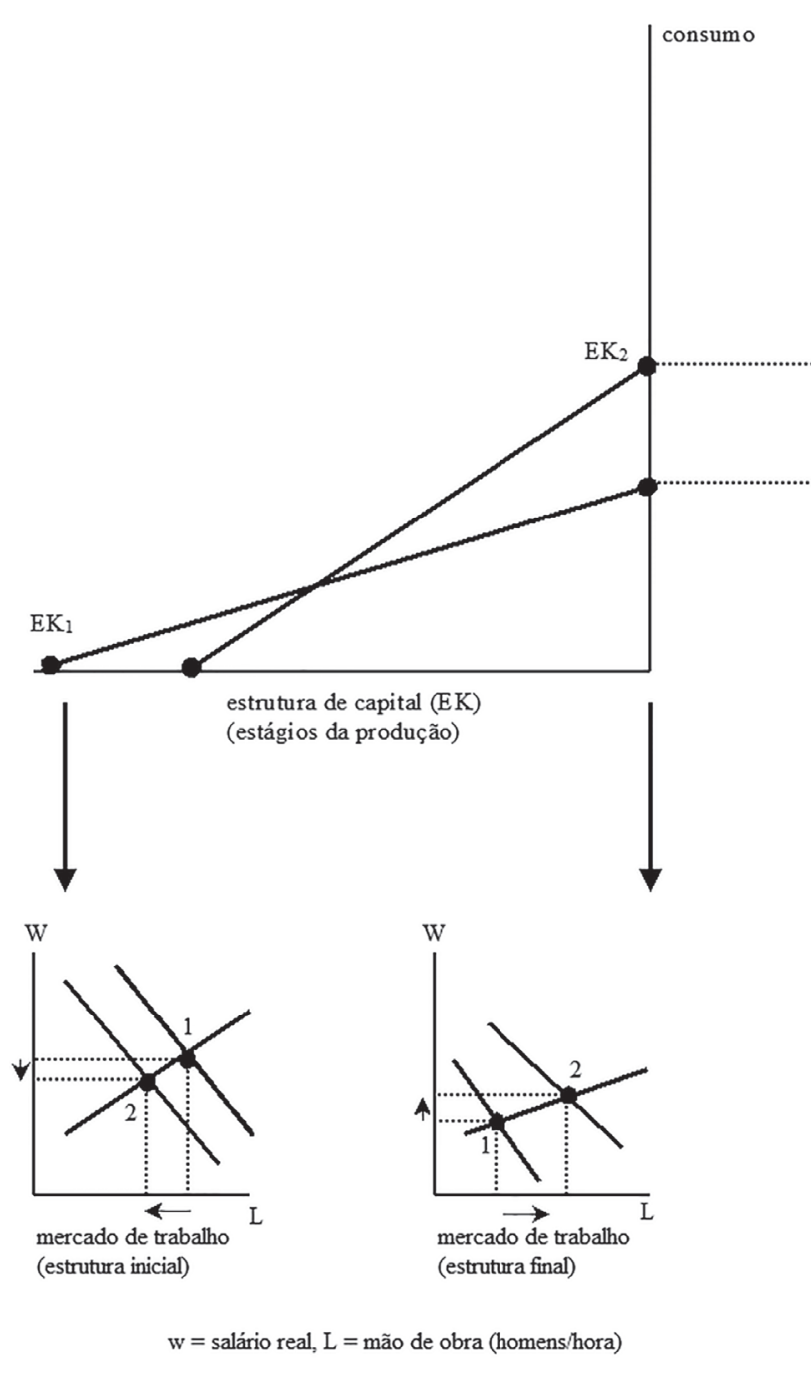

Com a queda da formação de capital da economia, tanto a fronteira de possibilidades de produção como a estrutura de produção deslocam-se para baixo: o consumo maior fortalece a demanda por bens de capital que estão próximos - em termos temporais - do produto final de consumo. Esse é o chamado efeito derivado da demanda. Por outro lado, a taxa de juros maior agora vigente desestimula a demanda por bens de capital afastados dos bens finais de consumo, na estrutura de produção Esse é o efeito do desconto temporal ou o efeito taxa de juros.

Mas, tal como no caso simétrico anterior em que o desejo de poupar aumentava esses dois efeitos só entrarão em conflito se o "in- vestimento" for concebido como um agregado. Na "macroeconomia" austríaca - que tra-

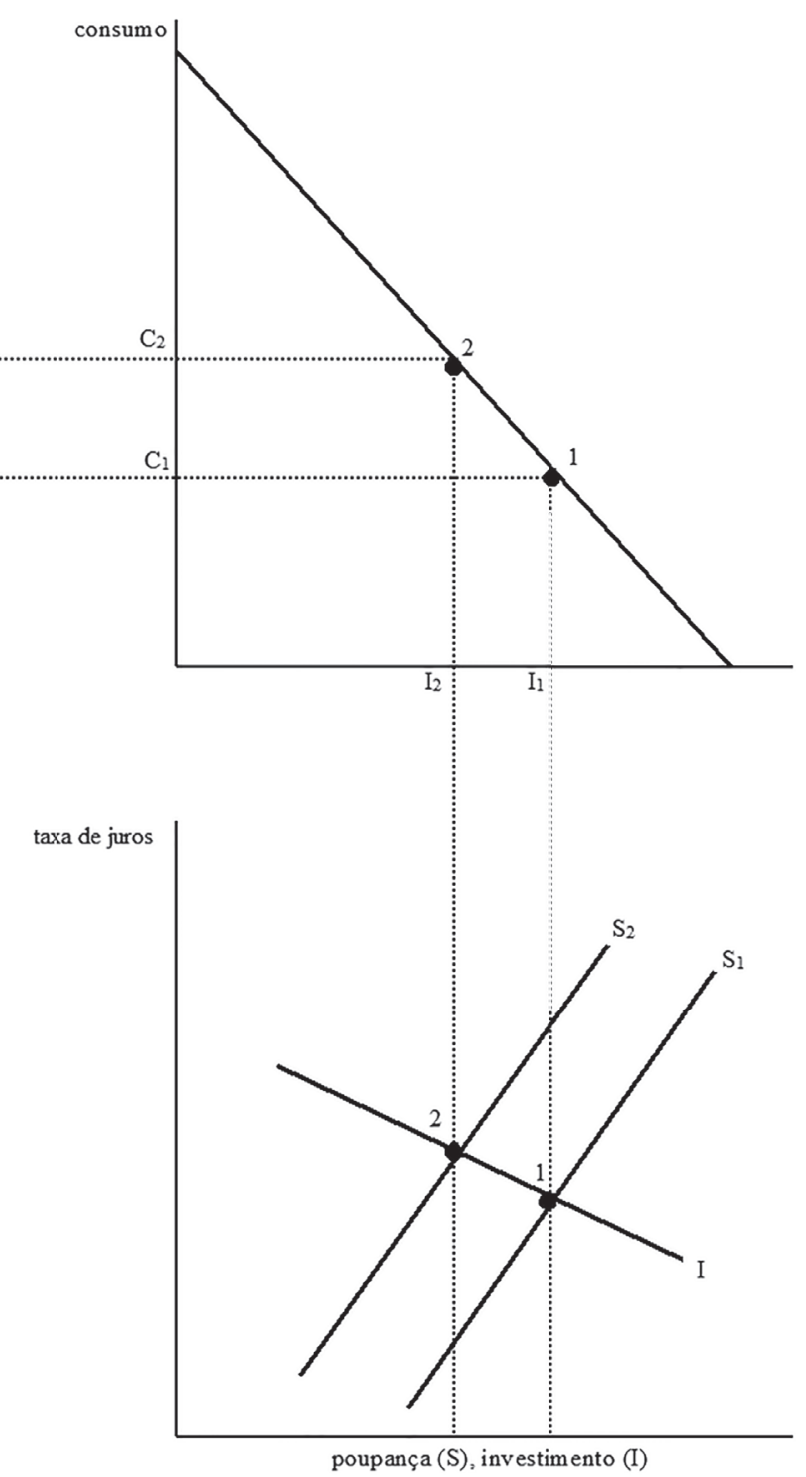

balha com uma estrutura de capital - o investimento é tratado como uma estrutura. E, tal como no caso anterior, os efeitos produzidos pelos investimentos sobre os vários estágios da produção são diferentes. Temos, mais uma vez, a Quarta Proposição de Mill.

No gráfico 10, vemos o efeito nocivo sobre a economia que uma preferência temporal pró-consumo provoca. Mais consumo significa menos poupança e, portanto, menos investimento e, por conseguinte, menor formação de capital. Em poucas palavras, significa retrocesso e não progresso. 
Para a escola Austríaca, o famoso paradoxo da poupança de Keynes soa como absurdo. De acordo com Keynes, qualquer redução nos gastos do consumidor iria resultar em um excesso de estoques, que por sua vez causariam cortes na produção, demissões e espirais baixistas na renda e nos gastos. A economia entraria em recessão, e a comunidade empresarial iria investir menos. A "solução" que apresentou foi que o governo aumentasse seus gastos.

O paradoxo da poupança sugere falsamente que aumentos na disposição de poupar gerariam desemprego. Os ciclos econômicos são provocados por poupança de menos e investimentos demais, e não - como acreditava Keynes - por poupança demais e investimentos de menos.

Sempre pensando em "agregados", Keynes sustentava que o mercado atua perversamente, impedindo que a poupança e o investimento se "equilibrem" partindo do pressuposto de que o desemprego e a ociosidade dos recursos eram a regra geral, defendia políticas contracíclicas fiscais e monetárias, e, em última instância, uma "socialização abrangente do investimento". Dizem que no início dos anos 1940 já não pensava mais dessa forma, mas não deixou nada escrito sobre sua mudança no modo de pensar, vindo a falecer em 1946.

Já Friedman, um incontestável defensor dos mercados, baseava-se em níveis ainda maiores de agregados, podendo-se, nesse sentido, dizer que era um "keynesiano". Aliás, é famosa uma de suas frases, "we are all Keynesians". A Teoria Quantitativa da Moeda, $\mathrm{MV}=\mathrm{PY}$ faz uso de uma variável agregada, o PIB (Y), negligenciando completamente a questão da alocação de recursos e as mudanças nos preços relativos provocadas pelas injeções de moeda na economia. É famosa sua alegoria do "helicóptero" despejando moeda sobre a economia de maneira uniforme. E centralizou sua atenção para a relação entre a oferta de moeda, estabelecida previamente pelos bancos centrais de acordo com uma "regra x", e o "nível geral de preços", outro conceito agregado rejeitado pelos austríacos. Se para Keynes a Grande Depressão fora provocada por poupança demais e investimento de menos, para Milton Friedman (1912-2006) fora provocada por moeda de menos circulando na economia.

Assim, tanto o keynesianismo quanto o monetarismo apresentam falhas comuns, apesar de o primeiro ser contra o mercado e o segundo ser a favor. Um desses defeitos é o uso de agregados; outro, a ausência total de qualquer teoria do capital; um terceiro, a aceitação de que os bancos centrais devem existir; e um quarto, para resumirmos, a desconsideração dos demais sete elementos da TACE, nele incluída a Quarta Proposição Fundamental de Mill.

A TACE se distingue das abordagens dos keynesianos e dos monetaristas por desagregar a economia e por conter uma teoria do capital, o que explica não apenas a alocação intertemporal de recursos, mas também que a melhor solução é a de mercado. Com efeito, Hayek mostrou que a coordenação entre poupança e investimento só pode ser obtida se a taxa de juros for determinada exclusivamente pelo mercado. Como observa Garrison,

Se os estoques varejistas fossem um investimento "representativo", então Keynes estaria certo. Nesse caso, o efeito derivado da demanda dominaria. Uma redução nos gastos do consumidor significaria menos reposição de estoques. E no geral, os investimentos dos estágios finais da produção ocorrem de acordo com os gastos do consumidor. Entretanto, o efeito da taxa de juros domina os investimentos de longo prazo - ou os estágios iniciais dos investimentos. Uma taxa de juros mais baixa pode estimular uma construção industrial, por exemplo, ou o desenvolvimento de novos produtos. 


\section{Gráfico 10 \\ Efeitos de uma Queda no Desejo de Poupar sobre Crescimento}

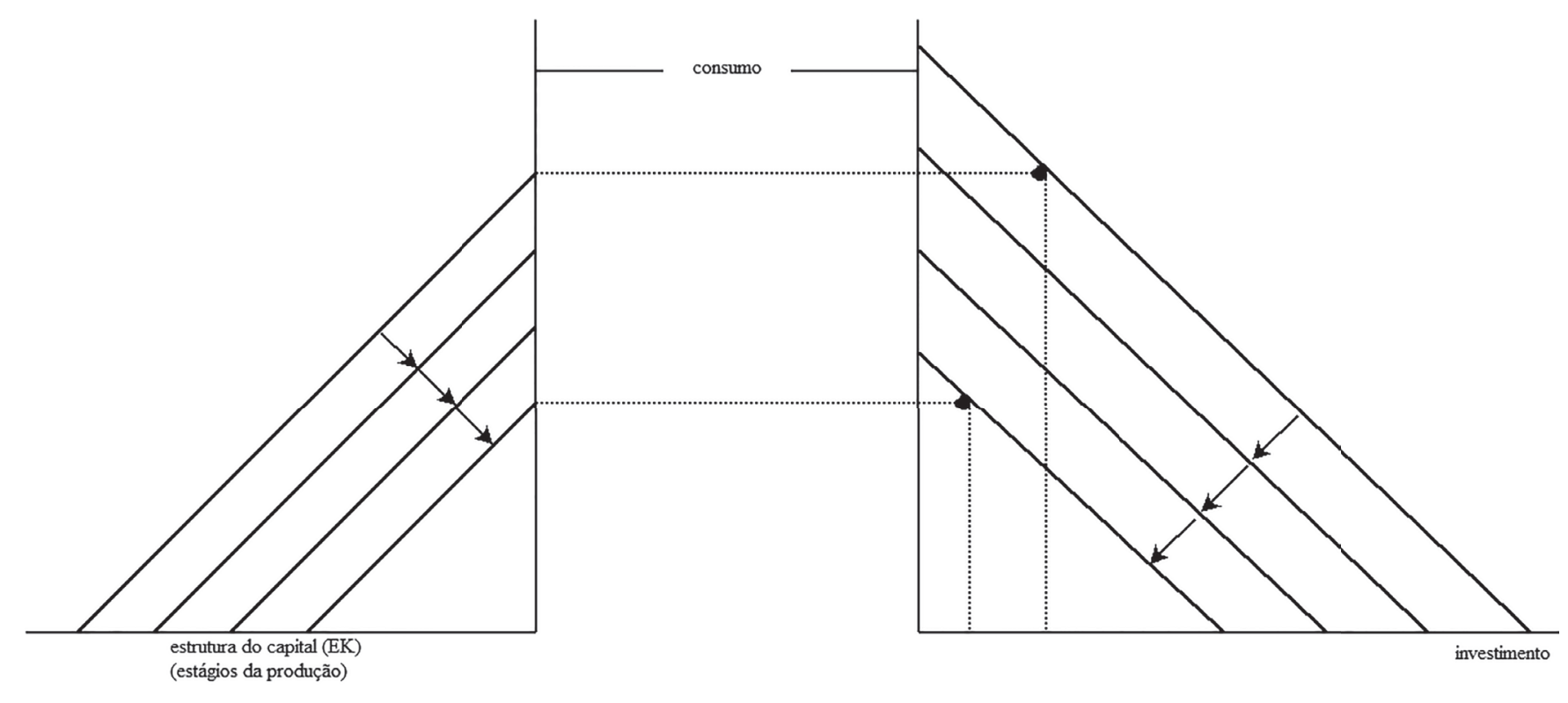

\section{VI - A DinÂmica dos Ciclos}

Para compreender corretamente a dinâmica da TACE, recomendo vivamente ao leitor que tenha interesse em se aprofundar no tema a leitura do livro de Roger Garrison, Time and Money: the Macroeconomics of Capital Structure ${ }^{14}$. Neste livro, que amplia e aperfeiçoa diversos trabalhos anteriores publicados em revistas especializadas, o autor expõe a TACE com maturidade, profundidade de conhecimentos não apenas da Escola Austríaca, mas da macroeconomia da mainstream, de maneira brilhante, utilizando-se de gráficos extremamente criativos e, exatamente por utilizar o instrumental gráfico - que, como sabemos, não segue estritamente a tradição austríaca - nos permite comparar com mais facilidade (especialmente os economistas) os pontos de vista da Escola Austríaca com os das escolas rivais. Esse é o grande valor do livro e estamos convictos que não é por usar

14 GARRISON, Roger. Time and Money: The Macroeconomics of Capital Structure. London and New York: Routledge, 2001. gráficos que Garrison se afasta da Praxeologia de Mises nem dos outros elementos básicos da tradição de Carl Menger, como o tratamento do fator tempo, do capital e da teoria hayekiana do conhecimento. Para nos certificarmos disso, basta entender os gráficos dentro da perspectiva austríaca.

Recomendo também a coletânea de artigos de Ludwig von Mises, Gottfried von Haberler (1900-1995), Murray Rothbard e F. A. Hayek, compilada por Richard Ebeling e com introdução e sumário de Roger Garrison, The Austrian Theory of the Trade Cycle $e^{15}$, editada pelo Mises Institute em 1996 e cuja edição original é de 1978, publicada pelo Center for Libertarian Studies. E, por fim, o livro memorável de Rothbard, recém editado pelo Instituto Mises Brasil, A Grande Depressão Americana, com introdução de Paul Johnson ${ }^{16}$.

${ }^{15}$ EBELING, Richard M. (Ed.). The Austrian Theory of the Trade Cycle and Other Essays. Auburn, Alabama: Ludwig von Mises Institute, 1996.

16 ROTHBARD, Murray N. A Grande Depressão Americana. São Paulo: Instituto Ludwig von Mises Brasil, 2012. 
Nas linhas que se seguem, vamos tentar condensar a interessante análise de Garrison, acrescentando-lhe nossos comentários. A figura 11 ilustra a dinâmica da TACE de uma forma muito interessante.

\section{Gráfico 11}

\section{A Dinâmica dos Ciclos}

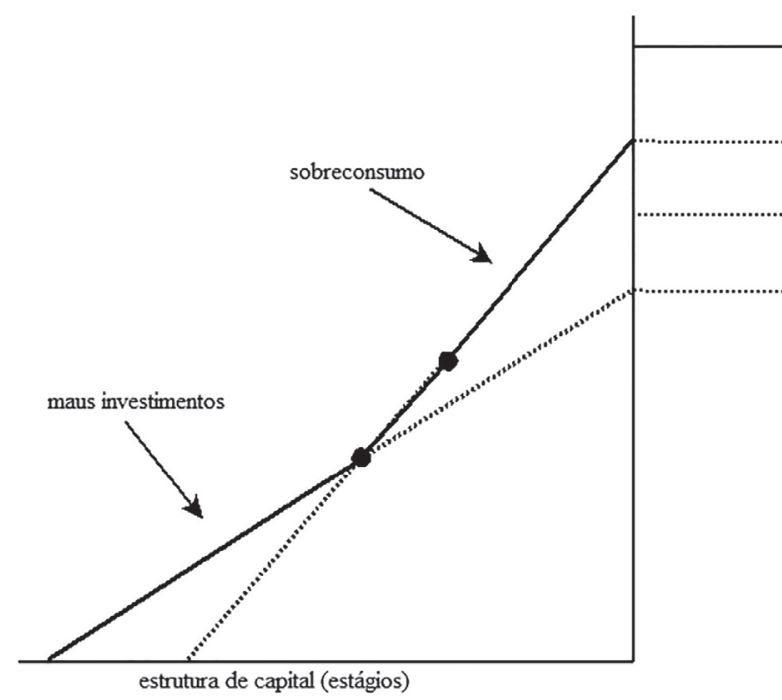

Suponhamos que o banco central aumente a oferta de moeda. Esse aumento da oferta monetária entra na economia em um ponto (ou pontos) específico da estrutura de capital e não uniformemente, como supõem os keynesianos e os monetaristas, através dos mercados de crédito. As chamadas "autoridades monetárias", literalmente, cria dinheiro do nada - já que atualmente não se exige qualquer lastro - e o coloca em circulação. Esse novo dinheiro $(\Delta \mathrm{M})$ passa a ser visto como poupança (é o mecanismo da poupança forçada ou artificial), um dos sete elementos da TACE a que já nos referimos no início deste artigo. Assim, a oferta de fundos para empréstimos (crédito) se desloca para a direita - mas sem que tenha havido - sempre é bom lembrarmos disso - qualquer aumento da poupança. Reagindo ao incentivo de uma taxa de juros menor, os agentes (ação humana) passam a poupar menos e a consumir mais. $\mathrm{O}$ resultado não será um novo equilí- brio sustentável, mas um desequilíbrio que, por algum tempo, fica encoberto pela injeção desses fundos adicionais de crédito. É nesses períodos que comentaristas, não vendo além do curto prazo, costumam afirmar que "a economia apresenta sinais de recuperação".

Portanto, essa injeção artificial de dinheiro através dos mercados de crédito cria 
ro, que por si só não representam recursos a serem investidos. A maioria dos escritos de Hayek direciona-se a um enfoque menor na relação básica entre dinheiro e o nível geral de preços, característica dos monetaristas, e a um enfoque maior no rompimento da coordenação intertemporal causada pela expansão do crédito.

Condições favoráveis de crédito, como de hábito, estimulam mais investimentos, o que sugere um movimento no sentido horário ao longo da FPP, no sentido do investimento. Mas os assalariados na realidade estão poupando menos (logo, consumindo mais), o que sugere um movimento anti-horário ao longo da FPP, na direção do consumo. A discrepância entre poupança e investimento se converte, no dizer de Hayek, em um cabo de guerra (tug of war) entre consumidores e investidores. Observando a dimensão do investimento (sentido horário) e a do consumo (sentido anti-horário), vemos que uma expansão do crédito "empurra" a economia para um ponto localizado além da FPP. Em outras palavras, está-se exigindo da economia mais do que ela pode oferecer. A resposta não tardará e, quanto mais os governos aumentarem gastos e os bancos centrais estimularem o crédito barato, essa resposta se tornará cada vez mais dolorosa.

A baixa taxa de juros baixa - porque é menor do que a taxa natural de Wicksell, outro economista que influenciou Hayek -, consistente com uma orientação mais voltada para o futuro, estimula o investimento nos estágios iniciais. Os projetos de longo prazo, associados aos estágios iniciais da estrutura de produção, tornam-se mais atrativos do que os de curto prazo, associados à produção nos estágios finais, próximos ao consumo. Mas, como os novos investimentos não são lastreados em poupança genuína, não haverá recursos suficientes para outros pontos da estrutura de capital e segue-se que a maioria desses investimentos jamais será completada. E, na verdade, o aumento da demanda dos consumidores atrai alguns recursos para os estágios finais, diminuindo ainda mais as possibilida- des de se completar a nova estrutura do capital voltada para os estágios iniciais.

A dinâmica desse ciclo, na linguagem de Mises, gera tanto investimentos excessivos (sobreinvestimentos) - mostrados no diagrama da FPP - como também investimentos errôneos ou maus investimentos (alongamento do triângulo hayekiano). Essas distorções são agravadas pelo sobreconsumo (como ilustrado na FPP e no triângulo de Hayek). O cabo de guerra que opõe consumidores a investidores leva a economia para além da FPP, algo, evidentemente, insustentável. A baixa taxa de juros favorece o investimento, e as restrições cada vez maiores de recursos impedem que a economia atinja esse ponto além da FPP. Essa estrutura de produção temporariamente em conflito (triângulos desconexos), ou seja, essa quebra de coordenação transforma, após algum tempo, um crescimento transitório - porque é artificial e, portanto, insustentável - em recessão e, possivelmente, em uma depressão. As tentativas dos bancos centrais de proverem cada vez maior liquidez só irão agravar os problemas que eles mesmos criaram, porque seus diretores, por mais inteligentes que venham a ser, nunca estudaram a TACE.

Essa é a gênese das estagflações e esse é o mundo em que vivemos atualmente.

\section{VII - Conclusões}

Vimos em que consiste exatamente a Quarta Proposição de Mill na concepção de Hayek e como ela decorre das três primeiras. Vimos também a interpretação neoclássica dessa proposição, suas críticas a Hayek e a resposta austríaca a elas. Em seguida, mostramos como em uma formulação teórica que contemple uma teoria do capital - no caso, a teoria austríaca do capital, com sua estrutura temporal de produção - a Quarta Proposição do economista inglês desempenha um papel muito importante, ao mostrar que consumo e investimento podem se mover em sentidos opostos, ou seja, que "a demanda de bens de consumo não é demanda de mão de obra". 
Por fim, reforçando ainda mais a Quarta Proposição, descrevemos a dinâmica dos ciclos econômicos, que são sempre desencadeados por fatores monetários, embora se manifestem primordialmente por fenômenos reais, como o desemprego de mão de obra. O Prof. Gottfried Haberler, referindo-se às injeções artificiais de crédito na economia, mostra sucintamente como essas emissões provocam falta de coordenação na economia:

[...] o tempo de produção é muito maior do que o tempo para a circulação do dinheiro. $\mathrm{O}$ novo dinheiro necessariamente entra no mercado para bens de consumo muito antes de que os novos processos sejam completados e produzam bens prontos para o consumo $^{17}$.

Em outras palavras, se um bem leva, por exemplo, oito meses para ser produzido e para ser posto à venda em uma loja de departamentos, a demanda por esse bem acontecerá antes desses oito meses. Isto é ausência de coordenação. Da mesma forma, não existirá coordenação se outro bem precisa de seis meses em produção até ser posto em uma prateleira de uma loja, mas a demanda por esse bem surgir depois desses seis meses. $\mathrm{Na}$ TACE, o elemento que coordena a demanda com a oferta é a taxa de juros. Por isso, quando os governos alteram artificialmente essa variável, a falta de coordenação será um fato líquido e certo. Haverá escassez imprevista ou formação de estoques indesejados.

Em suma, os sete elementos básicos da TACE e, muito especialmente, a Quarta Proposição de John Stuart Mill simplesmente demolem os argumentos keynesianos em prol de estímulos à demanda. Evidentemente, essa proposição por si só não é capaz de tamanha proeza, mas podemos afirmar que sem ela seria difícil atacar os argumentos de Keynes e os de seus seguidores. Definitivamente, estímulos à demanda não aumentam o emprego de mão de obra e, em circunstâncias especiais

${ }^{17}$ HABERLER, Gottfried. Money and the Business Cycle. In: EBELING (Ed.). The Austrian Theory of the Trade Cycle. p. 57.
- que descrevemos no artigo - tendem a agravar o problema.

O monetarismo, por sua vez, embora defenda os mercados livres, peca pela agregação, por negligenciar a Quarta Proposição de Mill e por também não trabalhar com uma teoria do capital, qualquer que viesse a ser esta. Por isso, o "remédio" receitado por Friedman para combater grandes recessões - injetar moeda maciçamente na economia - para os austríacos não é remédio, mas veneno, porque provoca ausência de coordenação entre poupança e investimento, vale dizer, entre oferta e demanda.

Para encerrar, enunciamos novamente a Quarta Proposição em uma linguagem austríaca: alterações na demanda de bens de consumo não são acompanhadas por mudanças proporcionais na demanda de mão de obra. Adicionalmente, uma queda na demanda de bens de consumo pode acontecer porque os indivíduos mostram-se mais dispostos a poupar, o que, sem dúvida, fortalecerá seu poder de compra no futuro. Mudanças na demanda de trabalho não são um simples espelho da demanda de consumo presente, mas refletem alterações nas preferências intertemporais.cos 